\title{
Past management affects success of current joint forestry management institutions in Tajikistan
}

\author{
L. Jamila Haider ${ }^{1} \mathbb{D} \cdot$ Benjamin $_{\text {Neusel }^{2}} \cdot$ Garry D. Peterson $^{1}\left(\mathbb{D} \cdot\right.$ Maja Schlüter $^{1} \mathbb{D}$
}

Received: 3 November 2017 / Accepted: 9 March 2018 / Published online: 15 March 2018

(C) The Author(s) 2018

\begin{abstract}
In the Pamir Mountains of Eastern Tajikistan, the clearance of mountain forests to provide fuelwood for an increasing population is a major source of environmental degradation. International development organisations have implemented joint forestry management institutions to help restore once-forested mountainous regions, but the success of these institutions has been highly variable. This study uses a multi-method approach, drawing on institutional analysis supported by Elinor Ostrom's design principles and socialecological system framework in combination with resilience thinking to help understand why some communities in Tajikistan manage their forests more sustainably than others. The application of the design principles provided helpful guidance for practitioners implementing joint forestry management. The social-ecological system analysis revealed both 'history of use' and 'tenant density' as positively associated with forest condition. However, we also identify limitations of snapshot social-ecological assessments. In particular, we illustrate the critical importance of considering historical legacy effects, such as externally imposed centralised governance regimes (that characterise many post-Soviet states) in attempts to understand current management practices. Our work shows how a more nuanced understanding of institutional change and inertia can be achieved by adopting a resilience approach to institutional analysis, focusing on the importance of reorganisation. Lessons learned from our analysis should be widely applicable to common pool resource management in other semi-arid forested landscapes as well as in regions with a strong centralised governance legacy.
\end{abstract}

Keywords Joint forestry management $\cdot$ Common pool resource management $\cdot$ Socialecological $\cdot$ Resilience $\cdot$ Tajikistan

L. Jamila Haider

jamila.haider@su.se

1 Stockholm Resilience Centre, Stockholm University, Kräftriket 2B, 10691 Stockholm, Sweden

2 Deutsche Gesellschaft für Internationale Zusamenarbeit (GIZ), GIZ Office Tanzania, 65 Ali Hassan Mwinyi Road, Dar es Salaam, Tanzania 


\section{Introduction}

In the Pamir Mountains of Eastern Tajikistan, the clearance of mountain forests for fuelwood is causing widespread soil erosion and negatively affecting a range of other important ecosystem services, such as the provision of timber building materials, conservation of wildlife habitat, recreational services and cultural values. Nearly all of Tajikistan's agricultural lands have been reported as suffering from some degree of erosion, with winter pastures being particularly effected (Saigal 2003). This degradation has occurred primarily due to overgrazing and the felling of mountain forests for fuelwood and timber. These forests are a classical common pool resource, insofar as resource users cannot be excluded, while resources consumed by one user are no longer available to others (they are subtractable) (Ostrom 1990). This makes their management challenging as there will always be an incentive to individually use more than is beneficial for the community as a whole.

Many scholars (e.g. Berkes 1989; Leach et al. 1999; Agrawal 2001; Agrawal and Gupta 2005) have proposed that decentralised community-based management can achieve both conservation and human well-being goals in common pool resources by enhancing a community's ability to self-organise. However, self-organisation is not always evident, especially in resource systems with a history of strong centralised governance (Barnes and Van Laerhoven 2013), which has led to non-governmental organisations taking a key role in the devolution of resource management (Shackleton et al. 2002; Blaikie 2006; Wright et al. 2016; Lund et al. 2018). In such instances, a common intervention strategy of both governmental and non-governmental development programmes has been to invest in building participatory governance mechanisms to help develop community-based natural resource management (Kumar 2002; Robinson et al. 2010). Joint forestry management (JFM) is one such approach that has been used to foster community-based management in many different parts of the world by transferring harvesting rights of forest products to rural people through contractual agreement with a relevant governing body (Robinson et al. 2010). Here we identify a tension between what scholars have observed in many cases: that resources users do self-organise, and the continuing practice of development organisations working to try to initiate collective action through community-based management planning. An interesting area of institutional scholarship is in contexts where practitioners aim to initiate collective action.

In the Pamir Mountains, joint forestry management has been introduced through a partnership between Deutsche Gesellschaft für Internationale Zusamenarbeit (GIZ) and the Tajik State Forestry Agency (which is commonly referred to by its Soviet name: Leskhoz) in an attempt to tackle problems of widespread forest loss and soil erosion. Yet the success and adoption of joint forestry management have varied across the region (Mislimshoeva et al. 2016). We examine the factors behind this variation using a novel multi-method approach that combines social-ecological institutional analysis and resilience thinking. Our institutional analysis first draws on the social-ecological systems framework (henceforth SES framework) (Ostrom 2007, 2009) to identify and analyse variables that may help explain differences in the outcome of JFM application, and secondly on Ostrom's design principles for robust property rights institutions (Ostrom 1990) to assess how conducive the actual design of joint forestry management in Tajikistan is to success. Both of these frameworks were developed by Elinor Ostrom through the analysis of conditions for successful self-governance across a large number of common pool resource case studies. In our Tajik case, property rights have been formally allocated to tenants under the JFM programme. Nevertheless, the de facto open access nature of forests in Tajikistan, even under 
joint forestry management, lends themselves to a common pool resource framework. Resilience thinking is used as a complementary social-ecological approach to identify relevant slow variables affecting the present-day outcome in forestry management.

This research seeks to inform both practice and theory by: (a) improving our understanding of the conditions under which joint forestry management can be successful in the Pamir Mountains; (b) providing concrete suggestions for how to improve the development of participatory resource management as pathway for improving the well-being of local communities; and (c) suggesting opportunities to better account for factors leading to successful management across space and time in complex social-ecological systems with strong historical legacy effects from a centralised government. Our study aims to address various aspects of the impacts of decentralisation on: forest quality, institutional empowerment, and the importance of historical and contextual factors that influence common pool resource management today (thereby addressing a gap in forestry decentralisation literature identified by Lund et al. 2018).

The paper proceeds as follows: we first describe forestry management and its history in the Pamir Mountains, followed by a description of our multiple method approach to understanding institutional variation and its effects on natural resource management in a dynamic historical context. We then present results on how independent variables identified in the SES framework (such as history of use and group size) effect forest condition (planned harvest) from survey and interview data collected from all JFM communities in the Pamirs (a sample of 25). The quantitative results are complemented with an in-depth comparison of three communities with varying JFM success. We conclude by discussing the implications of our findings for forestry management in the Pamirs and beyond.

\section{Background}

\subsection{Introduction to the case study: The Pamir Mountains, Tajikistan}

Tajikistan's transition from a command-and-control governance system to a market-based economy after independence from the Soviet Union in 1991 was turbulent (Giffen et al. 2005). Its economy, based primarily on cotton and aluminium exports, was vulnerable to external price fluctuations, and the economy could not create enough jobs for all the labourers coming from state-run farms and factories. The country precipitated into civil war (1992-1997) between the Tajik and Pamiri people, further contributing to economic stagnation. Since 2000, the GDP has expanded by almost 10 per cent, but a substantial part of the overall expansion is comprised of remittances from migrant workers in Russia and other Central Asian states (UN Data 2013). Still, 41 per cent of the population lives under the poverty line of $\$ 2.15 /$ day, with 75 per cent of the poor living in rural areas (World Bank 2009). The legacy effects of the transition and the civil war still have profound impacts on the country, with violent uprisings in 2012 and 2014 continuing to destabilise the region ('Tajikistan Clashes' 2012).

Gorno-Badakhshan Autonomous Oblast, often simply referred to as the Pamirs, is Tajikistan's largest province, constituting $64,200 \mathrm{~km}^{2}$, and is the poorest region of the country (Fig. 1). It is sparsely inhabited with a population of only 220,000 people (GIZ 2012). A strategically important buffer for the Soviet Union to China and Western influences to the east and south, the Tajik Pamirs benefitted from decades of Soviet modernisation through swift technological and economic development. As a result of large imports of 


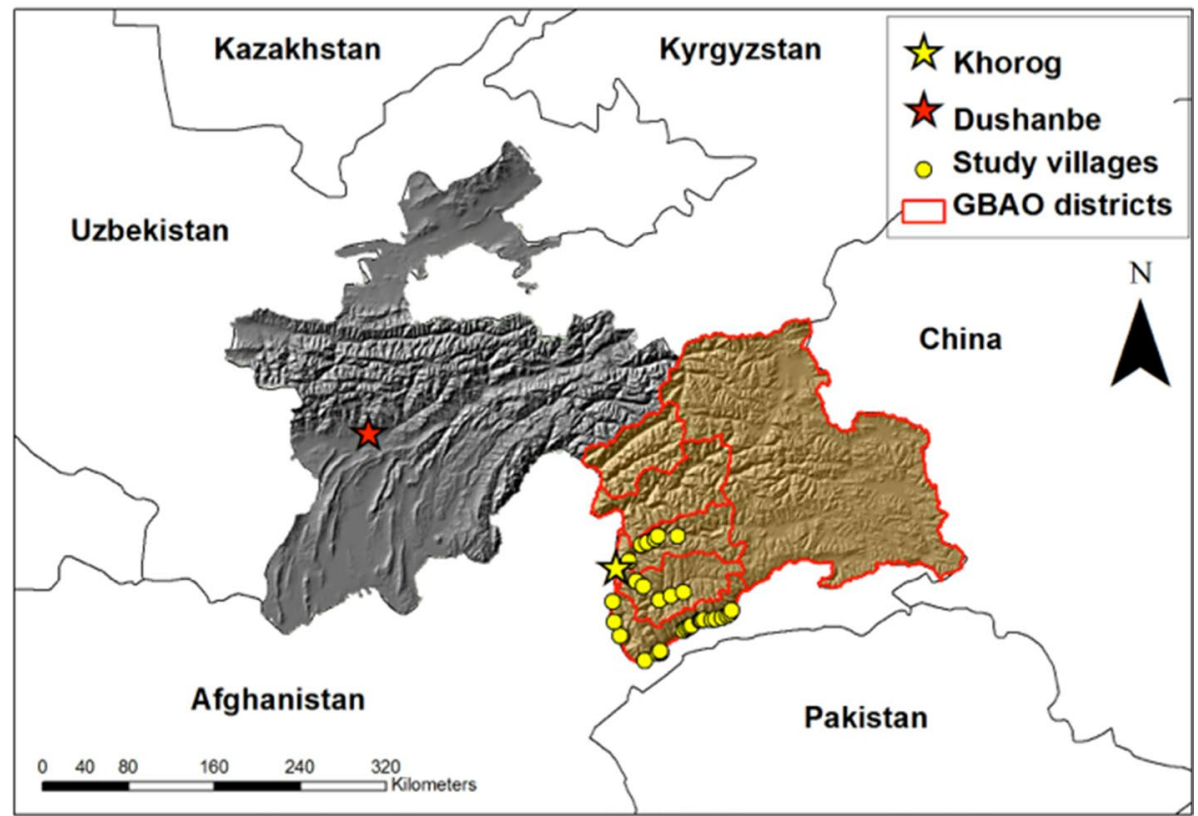

Fig. 1 Map of Tajikistan (coloured), with Gorno-Badakhshan Autonomous Oblast, or the Pamirs in light brown, and the rest of Tajikistan in grey. Yellow points indicate villages where JFM has been implemented and surveyed for this study. The topographic map demonstrates how villages are located on valley floors

fuel, fodder and food, its population quadrupled during the Soviet era (Breu et al. 2005). During the Soviet era, the central government recognised the inherent fuel limitations of the area and the ecological risk of desertification and initiated afforestation campaigns. Strictly regulated quotas on wood harvest were also imposed, and the fuel needs of a growing population were met by importing gas and petrol and supplementary wood sources. This liberal inflow of fuel resources ended abruptly in 1992, when Tajikistan fell into civil war. The Pamiri people rebelled against the central government in Dushanbe and became almost completely isolated from the rest of the world for 5 years. The absolute cut-off from imports, coupled with the collapse of the Soviet command-and-control governance systems, forced most people to turn to the forest for fuel, resulting in severe ecological degradation of forests within a decade (Herbers 2001; GIZ 2012). In the shift back to a subsistence-oriented economy, small fuelwood has once again become the primary source of fuel after decades of gas and petrol imports from Russia.

\subsection{Forest derived ecosystem services}

Forests occur only in the western Pamirs, where the average altitude is $4060 \mathrm{~m}$, precipitation is less than $200 \mathrm{~mm}$ and only 0.4 per cent of the land is arable (Breu and Hurni 2003; Hergarten 2004). The forests of the western Pamirs are primarily riparian as limited water availability restricts most tree growth to alluvial plains. They are commonly referred to as Tugai forests throughout Central Asia. Tugai forests are characterised by a mix of fast-growing tree species: poplar (Populus spec.), willow (Salix spec.) and shrubs 
such as seabuckthorn (Hippophae rhamnoides), and salt cedar (Tamarix spec. indicating desertification) and occur up to altitudes of $3400 \mathrm{~m}$ (Kirchoff and Fabian 2010). Despite forests covering less than $2 \%$ of the Pamirs, they remain an important source of rural livelihoods, providing fuelwood, grazing land and a source of collected fodder. The mean annual fuelwood consumption per household is estimated to be $3-4 \mathrm{~m}^{3}$. As the demand is much higher at approximately $20 \mathrm{~m}^{3}$ (Kirchoff and Fabian 2010), a large proportion of this demand is supplemented with an energy mix of dung, electricity and coal. The need for fuelwood and grazing pressure in the forest are the main drivers of forest degradation.

The forests are also of critical importance for controlling widespread soil erosion. Steady winds are a characteristic feature of many of the river basins resulting in the deposition of sand on fields and the denudation of fertile soil. Vegetation cover, however scarce, plays an important role in mitigating these processes (GIZ 2012). Where forests have been cut, sand dunes accumulate and threaten arable land and villages. Forests also play an important role in the rich culture of narrative, poetry and music of the Pamiri people that is closely intertwined with the landscapes they inhabit (Kassam 2010; van Oudenhoven and Haider 2012). Timber is used to construct the roetz (roof window) of the Pamir house, which represents four Zoroastrian elements, and poplar timber is used to construct the five main pillars of the house, representing the Prophet Muhammad, his daughter Fatima and son-in-law Ali, and their two children (Bliss 2006). Every traditional house in the Pamirs is constructed this way, and the structure is known to be resistant to earthquakes. Wild juniper twigs are used for the blessing of the home each New Year, and the wood of fruit trees has many specific traditional uses, such as utensils and bowls for ceremonial dishes (van Oudenhoven and Haider 2015).

\subsection{Forestry management in the Pamirs today}

In 2009, the Leskhoz began implementation of JFM with support from the development organisation Deutsche Gesellschaft für Internationale Zusamenarbeit (GIZ), as a means to regain control over forest resources. After the collapse of the Soviet Union, Leskhoz remained the management body only in name, with its staff reduced to a handful of individuals at the local level, operating without computers, without vehicles and often without electricity. In the context of unsustainable forest exploitation and the institutional downsizing and mismanagement of the Leskhoz, the goals of JFM defined jointly by GIZ and the Leskhoz were twofold: to reduce forest degradation and second, to ensure an equitable and regulated distribution of the benefits provided by the forest to forest user households.

The JFM approach in Tajikistan is based on a detailed use contract whereby Leszkhoz delegates 20 years of use rights for forest access to local people who become tenants. Leskhoz supports the tenants in developing an annual plan of forest management activities, including planned harvest and maintenance and monitors its implementation. The forest users have the responsibility of maintaining, developing and protecting their forest plot, and in return receive a share of the forest products, allocating $70 \%$ to the forest tenants and $30 \%$ to the Leskhoz. Approximately 2000 ha of state forestland in three districts of Gorno-Badakhshan Autonomous Oblast (GBAO) is currently under JFM management, which makes up $20 \%$ of actual forest cover in GBAO, involving about 350 households in 40 communities (Fig. 2 offers an example of a typical forest in the Pamirs). 
Fig. 2 Forest in Roshtkala valley, dominated by Populus and Salix understory. In the Pamirs, this forest is on the higher end of forest productivity

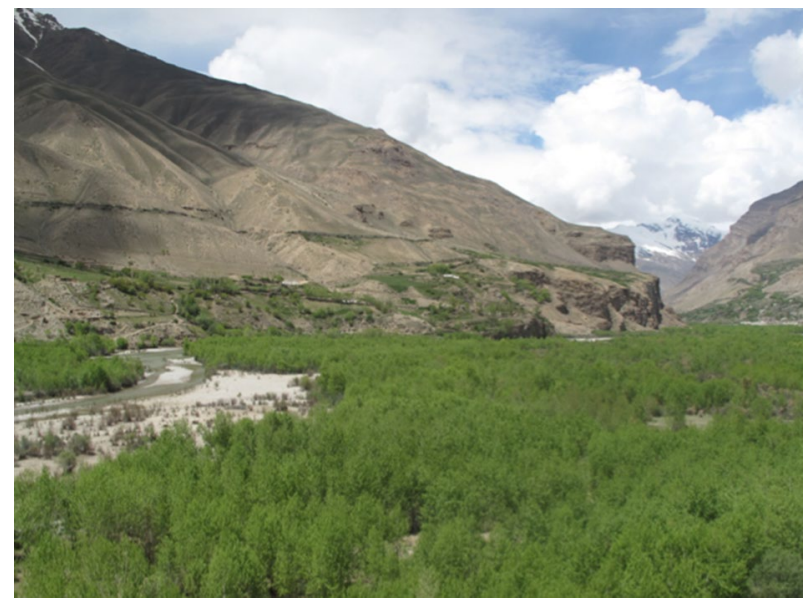

\section{Methods}

\subsection{Multi-method research approach: institutional analysis and resilience thinking}

We use a three-tier method to assess the institutional design of the joint forestry management programme, helping to understand variation in management success and the way in which institutional dynamics over time have influenced management outcomes (Fig. 3). Forests are managed in three different ways in the Pamirs: (1) the majority of forests are JFM (35 forests); (2) forests which have their own governance structure (3

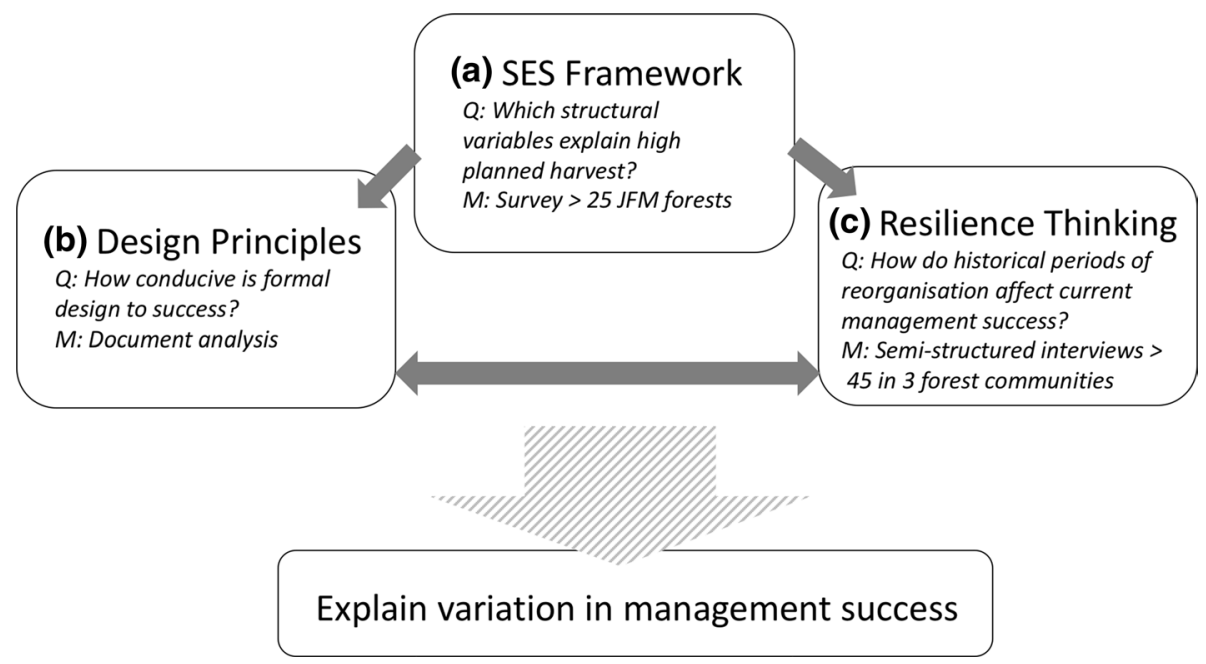

Fig. 3 Description of research steps to understand variation in successful forest management 
forests); and (3) Leskhoz forests which remain under jurisdiction of the Leskhoz (5 forests). We are only concerned with JFM forests in this study.

The SES framework is the central analytic method, with more descriptive (design principles) and qualitative methods (resilience approach) used to elicit the cross-scale dynamics we hypothesise to be present in the institutional variation of joint forestry management. The SES framework (Fig. 3a) was used to select relevant variables in explaining variation in planned harvest, testing through focus group surveys in each of the case study communities. In total, the survey was carried out in 35 JFM forests. The unit of analysis is JFM forest rather than village, since in a few cases, two villages share a forest. The survey was carried out by GIZ staff, called 'mobilisers' who have long-term relationships with the forest tenants. In order to conduct the survey, the responsible mobiliser followed the survey protocol (Appendix A) and asked the survey questions to a focus group of all forest tenants who were able to attend the meeting at this time. Dispute or conflict around answers within the group were recorded and used to elaborate on the results of the paper.

The experience of conducing the survey in focus groups of JFM forests revealed that many design principles were not being met in practice, which invoked the complementary document analysis (Fig. 3b) to answer how conducive the formal design of JFM was to success. Results from the survey helped identify which forests would be interesting cases in which to do more in-depth analysis (Fig. 3c) for the purpose of understanding how historical dynamics have shaped current management success. Three cases were selected to represent a range of successful JFM adoption. We use resilience as a conceptual framing to incorporate temporal and multi-scale dynamics into the analysis, complementing the SES framework. The following paragraphs describe each of these methods in greater detail.

\subsubsection{SES framework: analysis of factors explaining variation of planned harvest}

The SES framework is a multilevel, nested collection of variables that have proven to be relevant for explaining the emergence and success of local common pool resource management institutions (Ostrom 2007, 2009). The SES framework is meant to provide a common framework for social and natural scientists to think collectively about which factors in a given context contribute to more or less sustainable management of resources (Ostrom 2009). The framework breaks down a social ecological system into six core subsystems or first-tier variables: resource systems, resource units, governance systems, users, and interaction and outcomes, each containing second-tier variables which interact leading to specific outcomes. The selection of these categories of variables is based on three decades of empirical work studying common pool resources (Ostrom 1990; Gibson et al. 2005) and is being continuously adapted and expanded by scholars (see Epstein et al. 2013; McGinnis and Ostrom 2014; Leslie et al. 2015; Taggart-Hodge and Schoon 2016; Tyson 2017). The second-tier variables can be further unpacked to third- and fourth-tier variables and so on, to account for the specific variables of a case. Selection of relevant variables for a specific case and research question is an important and difficult step for an institutional analyst, and documenting the rationale for variable selection to assess forestry management is one important contribution we make with this paper to scholarship on common pool resource management (see Table 1).

In order to select second-tier variables from the framework that were relevant, attainable and useful for explaining differences in planned harvest of Pamiri forests as the ecological outcome of interest, we reviewed synthesis studies on the governance of forestry resources (Gibson et al. 2005; Chhatre and Agrawal 2008, Coleman 2011), the International Forestry, Resources and Institutions (IFRI) Database (IFRI 2008) and relevant case studies 


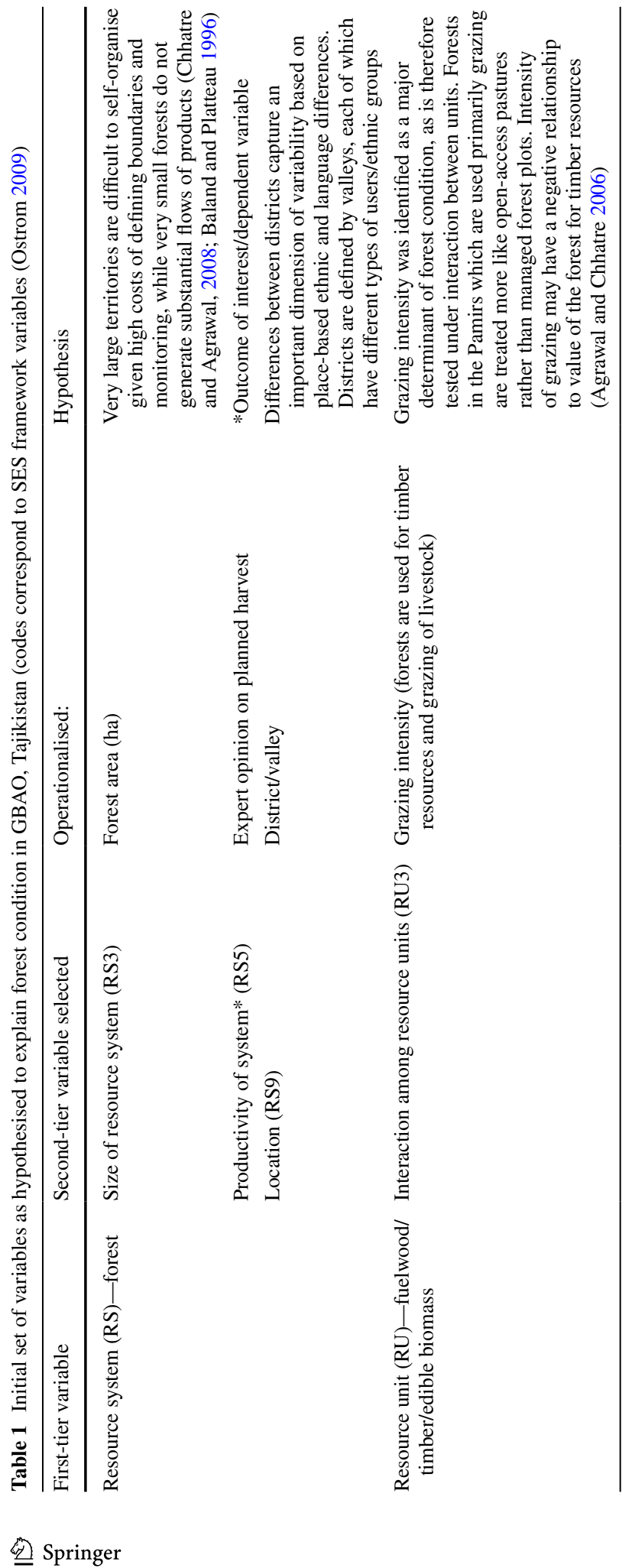




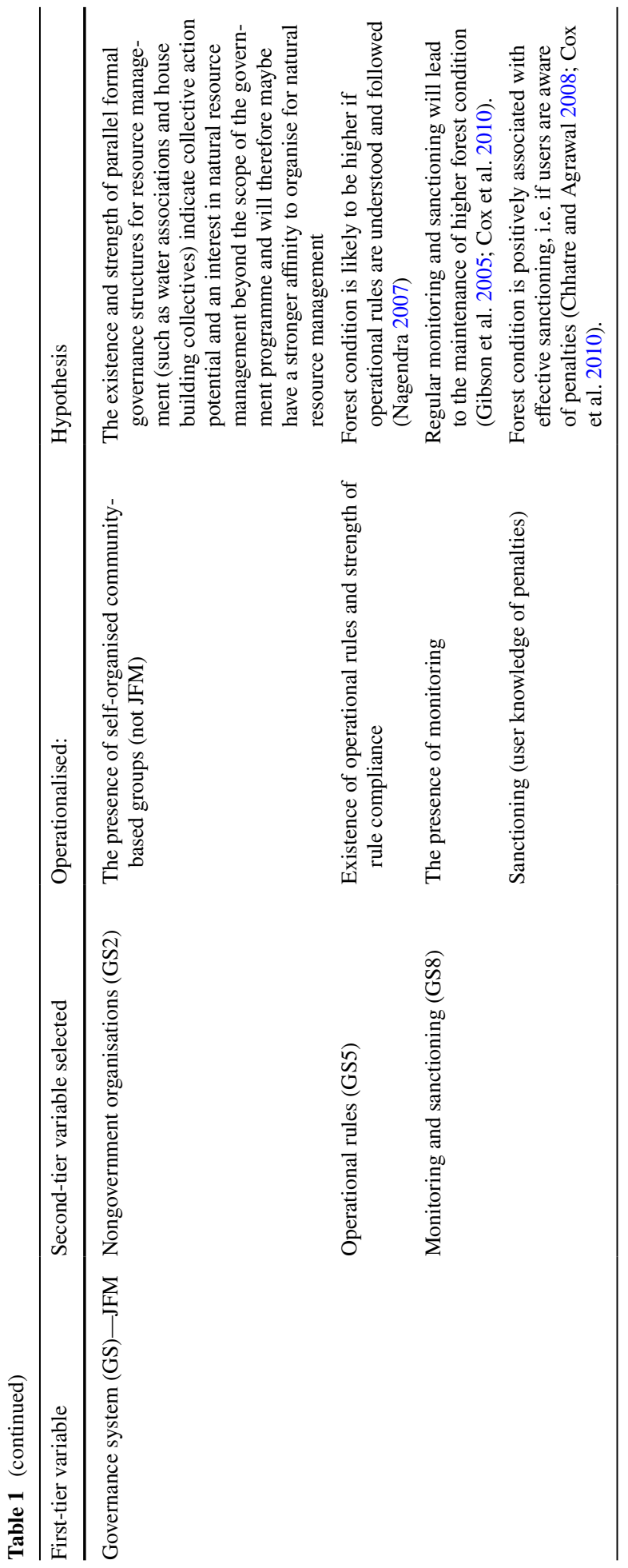




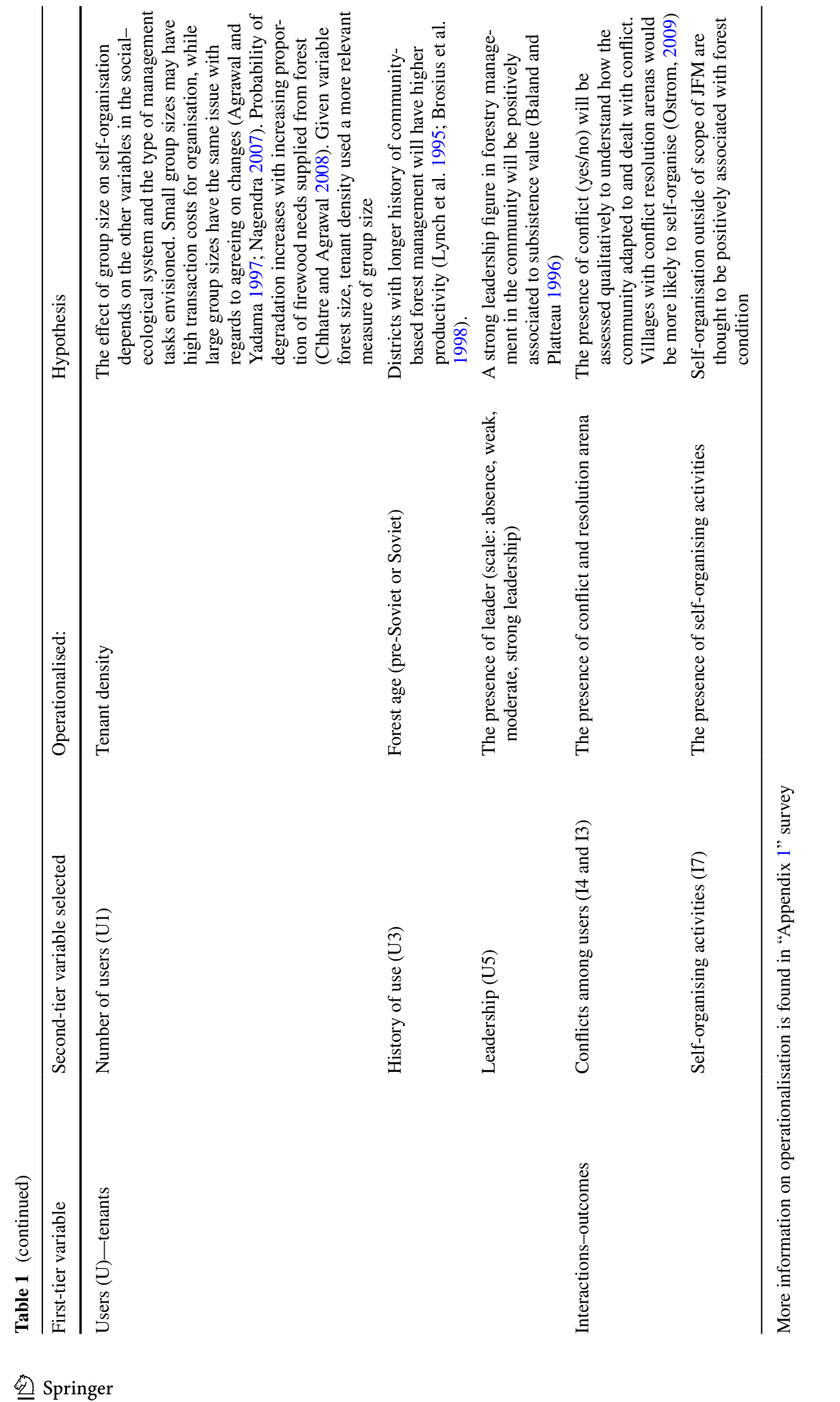


from other high altitude areas in India and Nepal (Agrawal and Chhatre 2006; Nagendra 2007). Based on this review, we selected 'planned harvest' as an outcome variable to act as a proxy for forest condition.

Planned harvest (a social-ecological variable) is an expert assessment by local foresters measured annually as part of management planning (we use 2012 data). Forestry officials from Leskhoz assess the forest each year for planned harvest (for timber and firewood) and establish the plans accordingly. This provided us with a reasonably consistent estimate of forest condition. The planned harvest measurement is an estimate, based on a reference forest. A 'good' forest is used a reference forest, characterised by a dense forest with little damage from grazing. Forest officials compare other forests to this reference forest by estimating (a) how the density of the forest compared to the reference forest, (b) how many new trees had been planted, and (c) whether or not grazing was a problem. No ecological data of forest condition exists across the case study forests, and therefore planned harvest is an appropriate indicator, taking both social factors (harvest need) and ecological factors (maximum sustainable yield) into account.

Variables were further selected through expert consultation: the field team of GIZ identified SES framework variables to be excluded which they thought were (a) not achievable given temporal and spatial data collection limitations, or (b) contextually irrelevant, or (c) confounding. Table 1 shows the variables that were selected for our analysis. We develop a set of hypotheses based on both theory and empirical observation to test which variables are associated with sustainable forest management (Table 1). Variables we considered to be relevant but did not test (due to a lack of variation) include: boundaries (all JFM forests are clearly defined with fences), proximity to road (all forests are along a road), collective choice rules (Leskhoz defines rules), constitutional rules (national-level Leskhoz defines rules), illegal use (too difficult to assess) and importance of resource (subsistence use for all).

The data for the selected SES framework variables were collected from previous assessments and through a field survey carried out in the same sites where forest condition was assessed by local officials. The surveys ( $N=25 \mathrm{JFM}$ forests) were conducted in focus groups of forest users in all the JFM forests in the western Pamir region (with groups ranging from 2 to 18 tenants), with some villages being grouped together for the focus group when they had two or less tenants available for the survey. Even in these cases, a separate survey was completed for each JFM forest. Responses were cross-checked with non-tenants for qualitative supplementary information to ensure the tenants' responses were not biased towards a positive representation of the JFM programme (survey found in "Appendix 1").

We examined the relationship between hypothesised explanatory variables (see Table 1) and estimates of forest productivity. We first examined the correlation among variables and then used hierarchical partitioning to identify variables that had a significant independent effect on estimated forest productivity. Hierarchical partitioning is a statistical method that analyses all possible models in a multiple regression to identify the contribution of each variable to the total variance, both independently and in conjunction with the other variables, to infer the impact of each variable (MacNally 2002). We conducted this analysis using the R statistical environment (R Core Team 2013) and the package 'hier.part' (MacNally and Walsh 2004).

\subsubsection{Design principles: institutional analysis of joint forestry management rules}

Elinor Ostrom developed a well-known set of institutional design principles of community natural resource management based upon her extensive empirical research (Ostrom 
1990). Here we use the extended list of design principles (Cox et al. 2010) to assess the potential for success of JFM given the formal rules in place under the auspices of JFM in the Pamirs (Fig. 3). The principles describe conditions under which collective action for sustainable resource use is more likely to be achieved (Ostrom 1990; Ostrom et al. 1999; Cox et al. 2010). They can be used to assess the potential of a given institutional design to lead to successful self-governance; however, they cannot explain variation in management success in common pool resource institutions that come about from different real-world contexts (the rules-in-use) of similarly designed common pool resource institutions. The design principles were intended for community-scale resources management and are therefore appropriate for this study, but it should be noted that modifications to the principles for larger-scale common pool resource management have been suggested by Lacroix and Richards (2015). Data on the design and implementation of JFM by GIZ were collected through participatory observation and document review (project documents, progress reports, monitoring reports).

\subsubsection{Resilience approach: assessing temporal and cross-scale determinants of the success of joint forestry management}

To analyse how collective action can be initiated by an external actor (such as GIZ), we complement the snapshot provided by institutional analysis with an analysis of the crossscale interactions of biophysical systems with their users and governance regimes over time using a resilience lens. Resilience as we use it here is the capacity of a social ecological system to continually change and adapt yet remain within critical thresholds to allow for development along its current trajectory (Folke et al. 2010, 2016). We draw on two particular aspects of resilience thinking to help understand the dynamics of institutional change: the adaptive cycle and slow variables. The adaptive cycle metaphor (Gunderson and Holling 2002) is used in this study to classify periods of systemic change and reorganisation and identify slow social-ecological changes that shape current patterns of forest condition and governance. The reorganisation phase is when novel changes can emerge, and windows of opportunity for change open up (Biggs et al. 2010), and is a central concept of resilience thinking (Folke 2006). It therefore also seems to be an appropriate focal phase for institutional scholars or practitioners interested in initiating collective action in common pool resource management. If our research had a stronger policy objective, we could have also drawn on punctuated equilibrium theory (True et al. 2007) to explain the path dependency of institutional characteristics following a period of crisis. Path-dependency theory (Mahoney 2000) could be employed as an additional method to analyse deterministic contingent events which have led to certain institutional outcomes. We find the adaptive cycle to be an appropriate starting point to consider which historical social and ecological factors matter (Darnhofer et al. 2016).

The cross-scale dynamics addressed here included temporal dynamics (past with present, and slow and fast variables), as well as various organisational scales (national and local scales). We looked for slow variables (sensu Walker et al. 2012) such as increase in grazing pressure and demographic change to see how the faster dependent variable under study (planned harvest) responded to variation of key variables which changed across temporal scales (in this case collapse of the Soviet Union and end of the civil war).

Forty-five interviews were conducted in three comparative case study villages in order to understand cross-scale interactions, particularly historical factors. The selection of villages was based on expert opinion to represent a range of outcomes: village A refused 
JFM; village B tried to implement JFM, but with limited success; village C successfully adopted JFM. The interviews were conducted in a semi-guided style (Patton 2002) where topics were specified in advance but were reworded as necessary throughout the interview. Purposeful sampling with maximum variation was used as the sampling strategy for the semi-structured interviews (Miles and Huberman 1994, Creswell 2007) in order to choose participants who were best able to provide information on changes in forest condition over time (i.e. elderly forest users; see "Appendix 2"). Transect walks were used to engage tenants in describing general resource use patterns.

We analysed resilience dynamics by identifying temporal periods that corresponded to different phases in the adaptive cycle - in particular the phases of conservation, crisis and reorganisation. We organised interview responses based on phases of forestry management and slow changes in social and ecological factors related to the contrasting forest management outcomes in the three villages by exogenous (e.g. property rights) and endogenous (e.g. leadership, collective action, need for provisioning services) drivers.

\section{Results}

\subsection{Design principles for collective action}

The evaluation of Ostrom's institutional design principles revealed that four design principles are met (clearly defined boundaries, proportional equivalence between benefits and costs, graduated sanctions, minimal recognition of rights to organise); two are only partially met (monitoring, nested enterprises), and two have not been met (collective choice arrangements, conflict resolution mechanisms) (Table 2). Column 2 describes whether the design principle exists in formal written records, and column 3 assesses the outcome in practice.

\subsection{Social ecological system variables explaining forest condition}

Significant positive associations were found between planned harvest and tenant density $\left(\operatorname{adj} R^{2}=0.414, p<0.001\right)$. However, we found no strong relationship between planned harvest and any of the other SES variables. Examining the relationship between villages and planned harvest revealed substantial differences between villages which had forests established before the formation of the Soviet Union and those planted during the Soviet Union (Fig. 4; adj $R^{2}=0.334, p=0.0012$ ). Although the SES variables are correlated with one another, the hierarchical partitioning analysis revealed that tenant density and forest type were the only variables to have a significant independent effect (Table 3). A multiple regression showed that planned harvest was positively related to tenant density for both planted and pre-Soviet forests, although harvests were much greater in pre-Soviet forests $\left(\operatorname{adj} R^{2}=0.5226, p<0.0001\right)$ (Fig. 4).

Forests established before the Soviet era were likely to be in better condition than forests established during the Soviet era. When we look at tenant density and forest history in combination (Fig. 4), we see that a lot of the observed variability in planned harvest is linked to the history of forest use and that three villages (Charsem, Bidej and Sovetobad) have much more productive forests than others. These are all villages that have pre-Soviet forests. Overall, forest condition improved with tenant density; however, there is only a relationship between tenant density and planned harvest in the Soviet-planted forests. The 


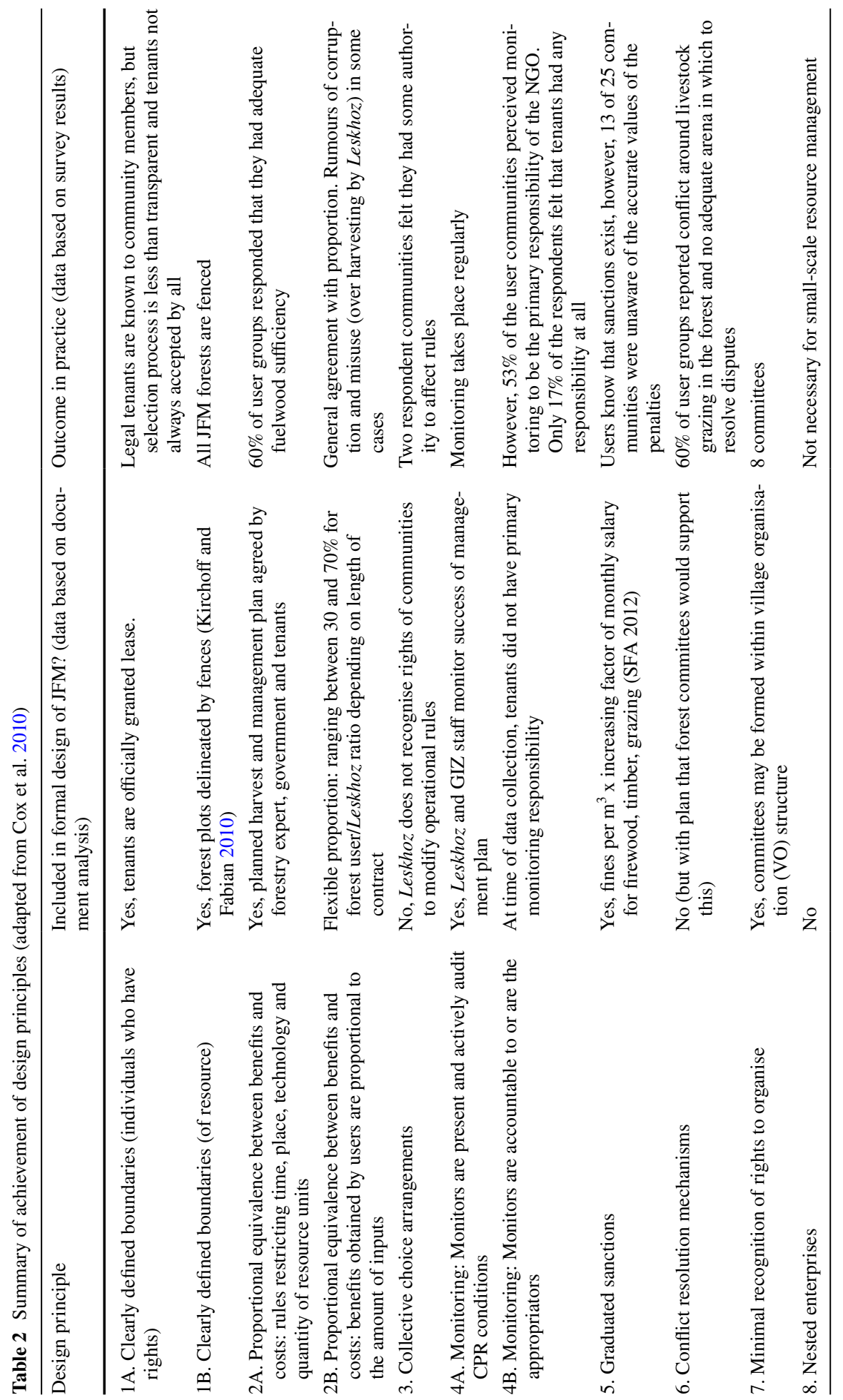



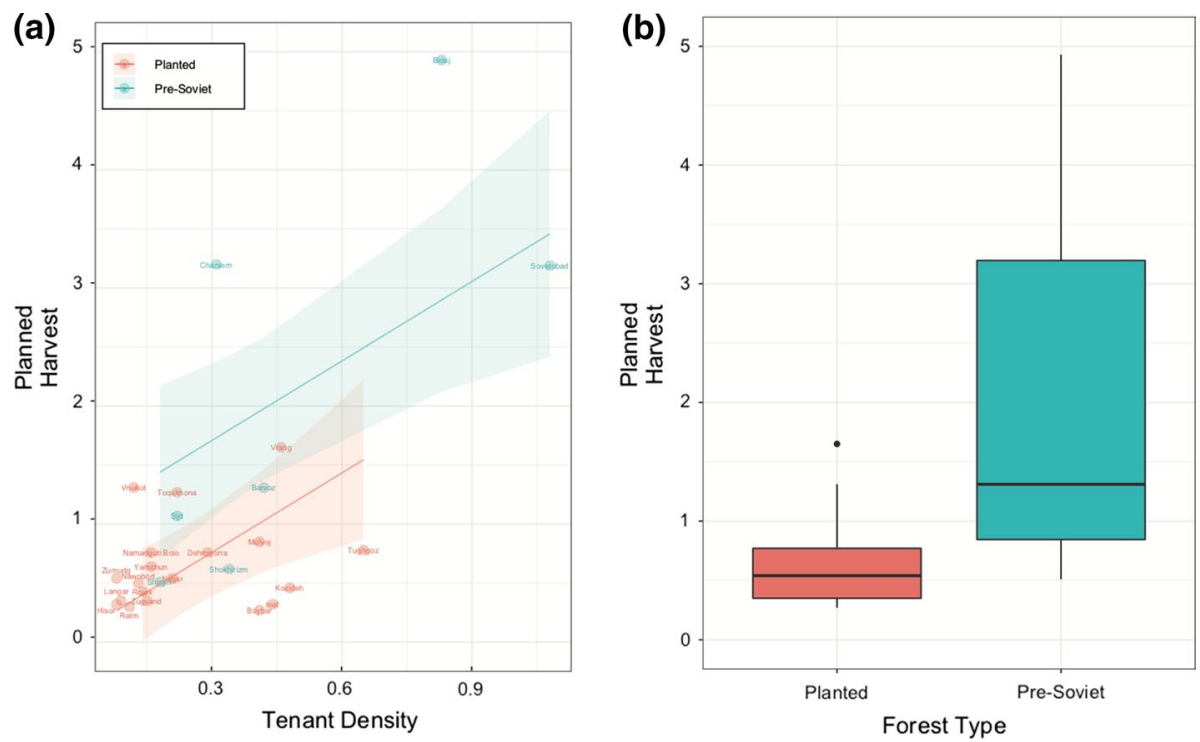

Fig. 4 a Relationship between tenant density and planned harvest is different between pre-Soviet- and Soviet-planted forests. b Productivity of pre-Soviet forests is much higher than Soviet-planted forests

mean value of planned harvest in these pre-Soviet forests is higher than that of Sovietplanted forests (1.0 vs. $0.73 \mathrm{~m}^{3} /$ ha/year) (see, for example, Fig. 2, which is pre-Soviet).

Leadership, penalties and fines were all identified as important variables explaining forest condition in the qualitative interviews, but were not found to be statistically significant.

\subsection{Applying dynamics from resilience thinking to institutional analysis}

The three villages selected for in-depth interviews contrasted primarily in their acceptance of JFM as a management approach. Village A chose not to adopt the JFM approach because the forest is their primary winter grazing land. The head of the regional forestry office allows 23 households whose property backs directly onto the forest to cultivate crops and even establish small buildings, despite this being strictly against the forest code, in order for them to actively manage the forest. The rest of the forest is open access and nearly completely deforested with only a few remaining poplar trees and seabuckthorn and is effectively used as pastureland. Livestock herding is the main source of livelihood (focus group, FG2) and is dependent on the forest: 'The forest is our only opportunity for grazing' [non-tenant 1, non-tenant 2 (see "Appendix 2")]. Many of the poorer people in the community said that they would want JFM because it would give them land to graze, but only if it was evenly distributed among all households-which would mean that each tenant would be left with less than 1 ha of forest. The current wealthier plot owners refused this proposal, since they would lose land they have depended on for over 25 years, and the livestock would be unlikely to survive the winter without access to the forest.

Situated in the lower Ishkashim valley, village B agreed to JFM as a management approach but failed to implement it successfully, regularly failing to meet management plans, resulting in eight contract cancellations in 2012 by Leszkhoz. The cancellation of these eight contracts exacerbated mistrust between the government and community 


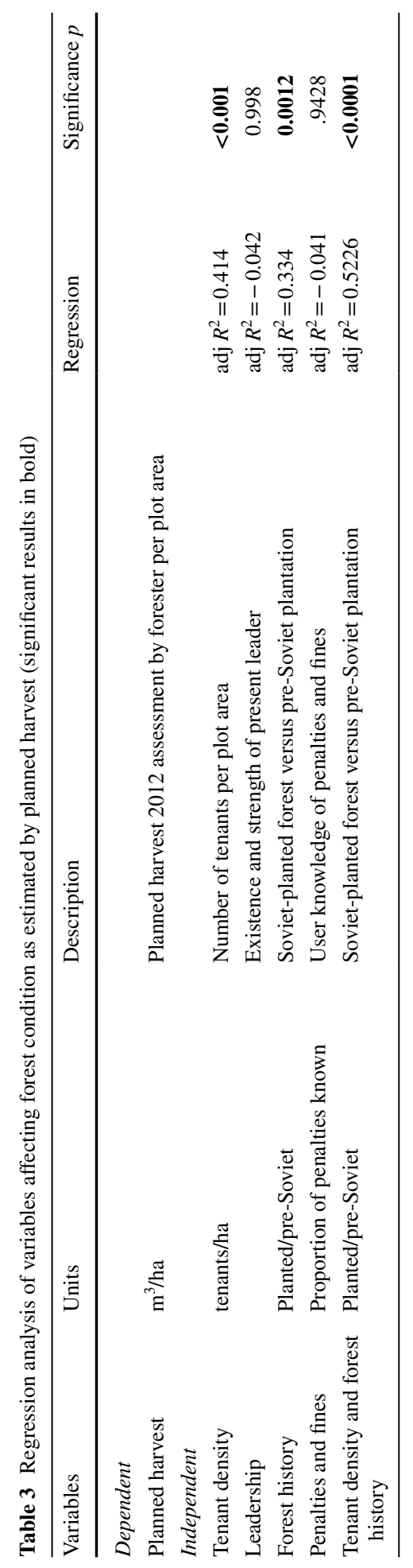


members (non-tenant 4). Due to the difficulty in managing the large number of uncooperative forest users, the Leskhoz has suggested paying one person in a full-time position to manage the forest, but nobody has accepted this offer, stating that the management of the forest is an impossible task (tenant T3). The forest was planted in 1957 by the Kolkhoz (Soviet collective farm) when the population of the village was 15 households, compared to 66 households today. During this time, a very strict local forest official managed the forest and it was in good condition, because of his strict, often physically abusive, enforcement of punishing any rule breakers (Forest Official 1). Another reason for the diminished responsibility community members feel towards management of the forest is a local military base, which shares a 400-m border with the forest, with soldiers allegedly stealing a lot of fuelwood at night as the base has no electricity or source of heating (tenant 2).

Village C readily adopted JFM and regularly meets its annual planed harvest targets. The village is also in Ishkashim district, but is located in the upper reaches of the valley, in the Wakhan corridor, which is inhabited by Wakhi people. The Wakhi are a small ethnic group who speak their own language (Wakhi) and practise combined mountain agriculture (Kreutzmann 2003). Initiated by the village head, seven men formed a forestry management group during the civil war to halt deforestation. These seven men still play an active role in forest monitoring, maintenance and conflict resolution today. In addition to strong leadership, village $\mathrm{C}$ places notable spiritual value on trees, much more so than other villages. Two sacred groves exist. One is the location of many religious ceremonies, while the other hosts an Islamic shrine that was built in honour of Hazarati Ali, who is thought to have brought Islam to the Pamirs in the sixth century (non-tenant 5). Every village in the Wakhan has shrines around groups of trees (Fig. 5).

Fig. 5 Shrine in village C, which consists of four planted poplar trees enclosed with offerings of goat trophies. These are holy trees, where people practise khudoi- in the name of God', a practice for communal prayer after an accident or illness. The family of the inflicted makes a fire using dried fallen branches and cooks the traditional meal, $B o j$, which they share with the community. While the holy site could not be considered to have the potential conservation value of a sacred grove, it holds symbolic significance with regard to the importance people attribute to trees (Photo: L.J. Haider 2012)

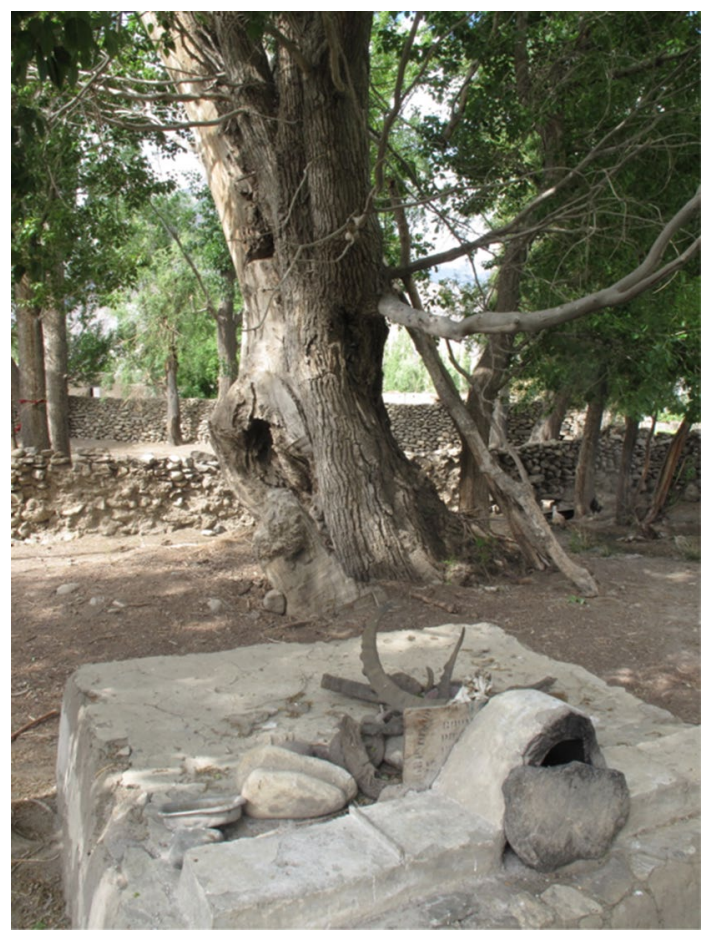


Three distinct eras emerged from the qualitative interviews: Soviet, civil war and current joint forestry management (Fig. 6). These eras correspond to property rights transitions from state owned, to lawless, to variable collective ownership. The main factors identified as influencing current attitudes towards forest conservation were sense of responsibility, historical leadership and demand for fodder. The way the different communities responded to the shock of the collapse of the Soviet Union and civil war influences current attitudes towards responsibility for the forest, as represented in the quotes in Fig. 6.

\section{Discussion: context and history matter}

Our multi-method approach to understanding the success of JFM in the Pamir Mountains has revealed the importance of historical factors in understanding management success in

\begin{tabular}{|c|c|c|c|c|c|}
\hline & $\begin{array}{l}\text { Phase 1 } \\
\text { (Soviet) r-K }\end{array}$ & $\begin{array}{l}\text { Phase 2 } \\
\text { (Civil war) } \Omega\end{array}$ & $\begin{array}{l}\text { Phase } 3 \\
\text { (JFM) } \alpha\end{array}$ & Key variables & $\begin{array}{l}\text { Effect on } \\
\text { forest } \\
\text { condition } \\
\text { in phase } 3\end{array}$ \\
\hline \multicolumn{6}{|l|}{ General trends } \\
\hline $\begin{array}{l}\text { Property rights } \\
\text { system }\end{array}$ & $\begin{array}{l}\text { Kolckhoz (collective farm); } \\
\text { Sovhoz (state farm); } \\
\text { Lezkkoz (forestry) }\end{array}$ & Lawless and open access & Joint ownership between government and communities & & $?$ \\
\hline $\begin{array}{l}\text { Dominant } \\
\text { trends for } \\
\text { management }\end{array}$ & $\begin{array}{l}\text { Afforestation: irrigated } \\
\text { forests }\end{array}$ & Deforestation & Reforestation & & $?$ \\
\hline \multirow[t]{2}{*}{$\begin{array}{l}\text { Village A } \\
\text { No } \\
\text { implementation }\end{array}$} & \multirow[t]{2}{*}{$\begin{array}{l}\text { (VO1) "During soviet times } \\
\text { the forest was very rich. It } \\
\text { was mostly willows and } \\
\text { seabuckthorn and dogrose. } \\
\text { Mostly big willows. You } \\
\text { could not even see the river } \\
\text { during soviet times." }\end{array}$} & \multirow[t]{2}{*}{$\begin{array}{l}\text { (FO1) "During the crisis } \\
\text { people took everything } \\
\text { there was to take." }\end{array}$} & $\begin{array}{l}\text { (VO1)"We are against JFM because there would be } \\
\text { nowhere for our cattle to graze" (demand for fodder). } \\
\text { (FO1) "The main problem is that during Soviet times } \\
\text { cattle were limited (maximum of } 2 \text { cows) and no more } \\
\text { than } 10 \text { small livestock. Today people have as many as } \\
\text { they can, and this is a problem." } \\
\text { "FŌi) "Öne year, we even had one tonne of seabuckthorn. } \\
\text { But now the price for these things is very low, and the } \\
\text { leskhoz no longer brings the container for us to bring the } \\
\text { products to a factory.". }\end{array}$ & $\begin{array}{l}\text { Decreasing } \\
\text { price for } \\
\text { NTFP }\end{array}$ & \\
\hline & & & $\begin{array}{l}\text { everything. But the rais says, the government is } \\
\text { responsible for everything. In the end, nobody is } \\
\text { responsible for anything." }\end{array}$ & Leadership & \\
\hline $\begin{array}{l}\text { Village B } \\
\text { Failed } \\
\text { Implementation }\end{array}$ & $\begin{array}{l}\text { (NGO2) "Everyone in } \\
\text { Kozideh was against the } \\
\text { forest, and nobody wanted } \\
\text { to help. But because we had } \\
\text { a strong government at the } \\
\text { time, we could make it } \\
\text { work. We started to plant in } \\
\text { 1957." } \\
\text { (FO3)"I was powerful and } \\
\text { strict. I wouldn't let anyone } \\
\text { take any trees. I would beat } \\
\text { them if rules were broken." }\end{array}$ & $\begin{array}{l}\text { (FO3) "Nobody cared. The } \\
\text { Leskhoz had no power. } \\
\text { Everyone was for } \\
\text { themselves." } \\
\text { (GO1) "Before everyone } \\
\text { used to participate in } \\
\text { community events, but now } \\
\text { they will only come if you } \\
\text { pay them." }\end{array}$ & $\begin{array}{l}\text { (GO1)"To extend the forests, means to extend grazing } \\
\text { ground. This is also the main limitation: we do not have a } \\
\text { big enough pasture territory (demand for fodder)." } \\
\text { (T3)"This is just a forest on paper. The Leskhoz created it, } \\
\text { cut it and sold it. It never belonged to us." } \\
\text { "Tenants have the right during the daytime, but not at } \\
\text { night because the soldiers have a right to shoot!" } \\
\text { (ḠÖ) "I "' was really interested in this system, and - - - - - - } \\
\text { afforestation. But when the JFM system started, I was } \\
\text { involved in these distributions, but when they chose the } \\
\text { tenants, nobody contacted me and nobody worked with me } \\
\text { anymore." }\end{array}$ & $\begin{array}{l}\text { Demand for } \\
\text { fodder } \\
\text { Sense of } \\
\text { responsibility }\end{array}$ & \\
\hline \multirow[t]{3}{*}{$\begin{array}{l}\text { Village C } \\
\text { Successful } \\
\text { implementation }\end{array}$} & \multirow{3}{*}{$\begin{array}{l}\text { (FO6) "Before, there were } \\
\text { not even houses here } \\
\text { because there was so much } \\
\text { sand. Now look, there is a } \\
\text { forest and a whole village!" }\end{array}$} & $\begin{array}{l}\text { (VO3)"After the collapse } \\
\text { the forest was completely } \\
\text { destroyed. We decided that }\end{array}$ & $\begin{array}{l}\text { (FG5) All the villagers use it, especially women bring } \\
\text { their cattle to graze. }\end{array}$ & $\begin{array}{l}\text { Demand for } \\
\text { fodder }\end{array}$ & \\
\hline & & \multirow[t]{2}{*}{$\begin{array}{l}\text { we should protect it, and we } \\
\text { therefore chose } 7 \text { people to } \\
\text { take care of the forest. It is } \\
\text { the main resource that we } \\
\text { have." }\end{array}$} & $\begin{array}{l}\text { When people need extra firewood for a celebration or } \\
\text { something, they can come get wood from us. It is our main } \\
\text { resource." }\end{array}$ & $\begin{array}{l}\text { Sense of } \\
\text { responsibility }\end{array}$ & \\
\hline & & & $\begin{array}{l}\text { (FG) "He [the Leskhoz leaderj did not allow any cattle in } \\
\text { at all. He was very strict, but he had no straf (fining } \\
\text { system). He would gather the cows in the shelter until the } \\
\text { owners came, and then they would discuss the violation. } \\
\text { This was the only way they could be stopped." }\end{array}$ & Leadership & \\
\hline
\end{tabular}

Fig. 6 Dominant phases of forestry management-results of qualitative interviews Legend: photograph phase 1: afforestation during Soviet times (1957 in Ptup Ishkashim, photograph by K. Khosimbekov); phase 2: deforested desertified landscape (2012 in Ishkashim, photograph by L.J. Haider); phase 3: Leskhoz raid on forest in upper Ishkashim, 2012 (2012 in Ishkashim, photograph by L.J. Haider). Interviewees are coded in brackets (see Appendix for full legend). $V O$ village organisation, FO forest official, NGO NGO, NT nontenant, $T$ tenant, $G O$ governmental official, $F G$ focus group 
the present day. We discuss insights from the three approaches: (1) a quantitative analysis of factors enabling collective action guided by the SES framework to explain institutional variability in the success of adoption of joint forestry management in the Pamirs, (2) using Ostrom's institutional design principles to identify enabling conditions for collective action, and (3) using the adaptive cycle to look at social-ecological dynamics. We discuss insights from each of these in turn identifying and highlighting opportunities for how existing frameworks can be improved, by breaking down the SES framework in contexts where external actors play a role in initiating collective action.

\subsection{Variation in success of JFM determined by the structure of the institutional and biophysical environments}

Variable history of use, which is an attribute of the users in the SES framework, is important to consider in contexts where management was externally imposed in the past. This result is further supported by the factors regulating tenant density. When Leskhoz assigns the number of JFM forest users per forest, they take forest quality into consideration to ensure sufficient revenue potential per forest user. This suggests that the pattern we observed of higher tenant density being related to higher productivity is due to Leskhoz's past decisions, and the absence of any relationship when only Soviet-planted forests are considered. In qualitative interviews, many tenants in the forest with poorer forest condition (village B) complained that many tenants made the management process tedious and not economically viable.

That pre-Soviet forests are positively associated with better forest condition was not unexpected. Not only are they more established forests in better ecological condition, but it is also likely that in the older forests, spiritual and cultural affinity is embedded in local tradition and culture. Our qualitative data suggest that cultural and spiritual affinities are important factors enabling sustainable forest management. As shown in Fig. 6, 'The forest is also very important for cultural events. When people need extra firewood for a celebration or something, they can come get wood from us. It is our main resource' (tenant 7). Our results therefore suggest the addition of cultural and spiritual value as additional second-tier variable attributed to the users. Furthermore, breaking 'history of use' (U3) down into third- and fourth-tier variables to explicitly include historical leadership and historical monitoring and sanctioning could be important to get a more nuanced picture of reality. Spiritual value could be a fourth-tier variable of 'importance of resource' (U8).

\subsection{Enabling conditions for collective action}

Collective action design principles can be useful in providing a rapid overview of the gaps and strengths in institutions, for both initiating and maintaining collective action (Barnes and Van Laerhoven 2013). We have found that particularly in the case of new participatory management institutions, such as JFM, design principles can help inform the institutional conditions to enable collective action around natural resources. GIZ and Leskhoz in Tajikistan have found them to be useful as guiding principles and, based on the recommendations of this study, have since modified their approach to initiating JFM in communities (e.g. in engaging with both present and past key actors, in communicating sanctioning practices more clearly and ultimately devolving more governance responsibility to community-based committees (personal communication with GIZ 2014). The document analysis and interviews summarised in Table 2 demonstrate that most design principles 
for collective action were at least partially met. The JFM programme has been successful in establishing clearly defined boundaries and creating appropriate incentive structures for some communities to encourage best practice (Table 2, design principles 1-2). With regard to design principle 3 , only two communities, out of 25 , felt they had any authority to influence the rules. This may be due to the legacy of a highly centralised forestry sector and will likely take more than one generation to change. During the Soviet era, the Leskhoz managed the forests with no input from communities, which drastically changed under the new era of decentralised joint forest management advocated by non-governmental organisations. While decentralisation has been widely associated with more sustainable forest management, its success is dependent on the ability of forest users to actively participate in the decentralised governance process (Wright et al. 2016; Lund et al. 2018). Explicit attempts at this in Tajikistan include involvement of the communities in monitoring, for example, which only very recently (in 2013) was transferred to forest users. We found in our study that it would be helpful to divide the 'monitoring' design principle into two component parts: a) monitoring the users and b) monitoring the resource (sensu Cox et al. 2010). The Leskhoz is responsible for monitoring the users but does this only whenever they happen to have a vehicle available to monitor rule breaches (for example, cows grazing on young saplings in the forest). Graduated sanctions exist, and while users know that sanctions have been prescribed, $50 \%$ of communities were unaware of what the penalties were and often not aware of what the sanctions were for (for example, grazing vs. extraction). Conflict resolution mechanisms are not in place, and in most communities, conflicts are managed on an ad hoc basis by village leaders. Forest tenants officially hold the right to organise in groups, but only two communities have registered forestry management organisations. Few studies have considered the legacy effects of centralised governance and activities (such as the ones mentioned above) and that these may be barriers to promoting self-organisation in common pool resource studies. Legacy effects on current day leadership are further discussed in the next section.

While the design principles were never meant as a blueprint to be used in the creation of institutions, they outline principles that characterise robust resource management institutions, particularly for common pool resources (Anderies 2004), and as we found in this case can open up a space for dialogue and analysis among users and managers, helping to break down an otherwise seeming overwhelming problem to one that can be tackled systematically. It is important to note that there may be great variation in the specification of design principles across different social and ecological contexts. For example, greater deviation from these principles has been documented to occur in semi-arid ecosystems (such as the Pamirs), due to a more variable environment and in locations where there are greater tensions between formal and informal governance structures (Quinn et al. 2007).

\subsection{Understanding reorganisation of forestry management key to understanding current status and future trajectories}

Resilience thinking offers a way forwards for institutional analysis to address important historical dynamics (such as historical centralised governance and leadership) that explain institutional variation today by (1) focusing on the dynamics of SES, particularly the reorganisation phase after a major system change, and (2) assessing the effects of slow variables on the capacity of the system to adapt.

As emphasised by Pierson (2004), taking a snapshot of current institutional behaviour may deemphasise the processes through which institutions take shape over time. 
Understanding historical legacy effects on current conditions is particularly important in places like the Pamirs, where the history of the Soviet Union and its aftermath has left a lasting imprint on the economic, political and social make-up of communities and the ways in which they are governed, Pierson (2004) argues that because social processes are path dependent, and that many social causes and outcomes are slow moving, explaining particular outcomes requires situating them in a temporal sequence of events. Analysis of the reorganisation phase in the Pamirs (starting in ca. 1997 after the civil war ended) demonstrates how historical drivers can influence institutional outcomes in the present. Our interviews (Fig. 6) demonstrate how legacy effects from three distinct institutional phases can strongly determine which variables have the greatest influence on current management systems. The narratives show that leadership qualities and a feeling of responsibility over the forest can be treated as slow variables, which possess path-dependent traits. For example, in village B, a forest tenant explained: 'This is just a forest on paper. The Leskhoz, created it, cut it and sold it. It never belonged to us' (tenant 3). A particularly violent local leader during Soviet times discouraged people to take responsibility of the forest as a communal resource. This attitude remains today, and every household in the village has refused various offers from the Leskhoz to take on leadership roles in forestry management, despite payment incentives.

Many of the slow variables such as the ones described above and demographic pressures of grazing shape how planned harvest (as the faster dependent variable) responded to changes in key variables such as property rights that change over time (in this case collapse of the Soviet Union and end of the civil war). For example, the responsibility over forest management felt by community members in village $B$ versus village $C$ could be traced back to how changes in leadership influenced institutional formation over time.

\subsection{Reflections on multiple methods and different ways of framing institutional analysis}

There exists an inherent tension between the tools and frameworks (e.g. Ostrom 1990, 2009) that are commonly used to analyse institutional dimensions of resource management and the dynamism we know is in inherent to social ecological systems (Anderies 2004). This paper furthers the integration between resilience thinking and institutional analysis (Daedlow et al. 2013). We believe better integrating SES analysis with approaches that take historical processes into account, e.g. through the analysis of slow variables phases of the adaptive cycle (as done here, and see Goulden et al. 2013), or the construction of historical timelines (Resilience Alliance 2010). We offer the following recommendations for scholars undertaking an analysis of the capacity for collective action in natural resource management in cases where there was strong external influence in the past: (1) incorporate explicit historical variables into the SES framework when assessing variation in management success and (2) embed the assessment of fast explanatory variables in the context of slow variables.

The multi-methods approach taken in this study (e.g. Table 2 and Fig. 3) was an attempt to reconcile this tension by examining both the structural elements of the SES of our study system and the dynamics of underlying slow variables. Our experience is similar to that of Basurto et al.'s (2013) in suggesting that the SES framework should be used as a starting, rather than an end point in the study of social-ecological systems. Moreover, we propose that an approach that combines different methods is necessary to help enrich our understanding of the importance of both local contexts and key variables that shape the outcomes 
of interest over time. We also found that a mixed-method approach can help identify ways in which general frameworks can be tailored to help understand local cases. For example, our findings on the impacts of strong centralised management legacy effects on present-day leadership and self-organisation potential reveal new sub-tier variables to consider such as history of use, leadership and spiritual values. It would be useful to explore the impact of these factors on the success of self-organisation of community natural resource management in other cases to move towards mid-range theory development. However, our study demonstrates the challenge identified by Ban and Cox (2017) that the SES framework lacks user guidance, which results in a plethora of individual research conducted with little coordination, generating problems with establishing causal inference or theory testing across cases (also identified by Lund et al. 2018). Rather, the value of the framework may lie in deep analysis of individual cases studies, to break down the mechanisms of the complex phenomena observed (Ban and Cox 2017), which is certainly the value we found in using the SES framework in our case.

The combination of the quantitative survey with qualitative interviews also allowed us to mitigate limitations of the survey related to low sample size, self-censorship and difficulties of accurate translation that may explain why some key variables that emerged from the qualitative approach were not significant in the quantitative analysis. Many participants may be unwilling to report illegal activity, and respondents may be pressured by NGO staff or government to provided responses in line with how things 'should' be. Furthermore, the survey was translated from English to Tajik (the official language of Tajikistan), but some respondents were uncomfortable with Tajik, and therefore, the survey had to be administered in Shugni (a local language) or Russian. This meant that in practice there were often up to four languages spoken during any given focus group, which may have affected clarity of the survey for both the respondents and interviewers. Testing relationships among many social-ecological variables requires a large sample, but collecting large samples is often not possible due to difficulty, cost and the nature of the system being studied (Poteete et al. 2010), such as in the Pamirs where we took an exhaustive sample of all JFM forests, amounting to only 25 cases. Furthermore, large $\mathrm{N}$ cross-comparison work is necessarily blind to the nuance of cases that can never be integrated into a meta-analysis. On the other hand, it is important to be aware of the limitations of the qualitative approach: it is difficult to get an overview of relevant themes and issues in the region, and it is difficult to generalise from three cases. Our iterative approach between quantitative and qualitative data collection and analysis allowed us to generalise our results and contribute to theory development, while at the same time maintaining a nuanced perspective in a given place.

\section{Conclusions}

The social-ecological system framework (Ostrom 2009) was useful in exploring why some communities in the Pamir Mountains adopted joint forestry management more successfully than others (with planned harvest as a proxy variable). Tenant density and historical use both helped explain higher planned harvest. Taking a snapshot of a social-ecological system at a particular point in time is not sufficient to explain social or ecological outcomes, particularly in settings characterised by harsh environmental conditions and a strong legacy of centralised management. In such cases, a dynamic approach incorporating slow variables is necessary. Implementers should be aware of the importance of the effects of historical legacy, and institutional analysis may benefit 
from a more dynamic analysis of the reorganisation phase. Resilience thinking offers a useful set of tools for bringing historical dynamics into social-ecological analysis. We found that differences in forest condition between communities under JFM to be strongly influenced by the historical dynamics of a given place, with a longer history of use, and positive leadership through crisis and reorganisation periods contributing towards more successful outcomes. We call for more research to improve our understanding of how to enable collective action in contexts where there was strong state involvement in resource management in the past (like post-Soviet states). We have much to learn at the interface of institutional scholarship and participatory resource management such as widely promoted by the international development community. Design principles were adopted as a useful framework by the implementing non-governmental organisation and government in designing the expansion of joint forestry management through other parts of Tajikistan as evidenced in the adoption of the Forest Code 2011 (Tajikistan 2011).

Acknowledgements This research would not have been possible without the support of GIZ Tajikistan and Leskhoz GBAO. Particular thanks for field assistance from Behruz Ilnazarov, Dilbar Zevarova, Donish Doniyor, Haqrizo Nurmamad, Manuchehr Fezakov, Sorbon Kholiqnazarov, Zarifhon Gulchinov and Zaynura Shodmonbekova. GIZ sponsored the fieldwork: thank you especially to Michael Angermann for his enthusiasm and support. The research was undertaken, while LJH was supported by a Gates Cambridge Scholarship at the Department of Geography at the University of Cambridge, UK. Thank you to Professor William Adams for his role in helping conceptualise the research questions and field design and Toby Gardner for support in research design and revisions. LJH is grateful for many conversations with colleagues at the Cambridge Department of Geography and the Stockholm Resilience Centre. The analysis and writing took place at the Stockholm Resilience Centre with support from MISTRA, the Swedish Research Council FORMAS (Ecosystem Services 1439903), and the European Research Council under the European Union's (FP/2007-2013)/ERC Grant Agreement 283950 SES-LINK.

Open Access This article is distributed under the terms of the Creative Commons Attribution 4.0 International License (http://creativecommons.org/licenses/by/4.0/), which permits unrestricted use, distribution, and reproduction in any medium, provided you give appropriate credit to the original author(s) and the source, provide a link to the Creative Commons license, and indicate if changes were made. 


\section{Appendix: 1}

Name of GIZ Mobilizer:

ID of questionnaire: (e.g. 01)

Name of village:

Population of village:

Name of Forest (if applicable):

GPS coordinates of forest:

\section{Survey instructions}

- $\quad$ Ask all question in the order they are provided here

- $\quad$ Record the answers of the forest tenants, NOT your own opinion

- Make note where the answers differ (this is interesting for qualitative analysis)

- $\quad$ Tick the box beside all answers that are relevant. For example: $\mathbb{x}$

Question: What are the factors that enable maintenance or improvement of forest resource values of forests in GBAO over time?

Outcome: This study will help to strategically invest resources in villages which are most likely to manage forest resources effectively and sustainably and target on improving factors in villages which need more investment. The study offers a unique case study to global datasets (IFRI and IAD) from a semi-arid mountain desert steppe ecosystem with post-soviet governance structures.

Research method: Survey

\section{Questions for the mobilizer to be filled out ahead of time}

1. What is the size of the forest? (IV4)

2. How many legal tenants (households) hold leases on this forest? (IV5)

3. What is the altitude range of the forest $(\mathrm{m})$ ? m

4. How far (in $\mathrm{km}$ ) is the nearest road? $\mathrm{km}$

5. How far (in $\mathrm{km}$ ) is the nearest market (where wood is sold)?

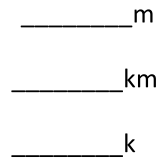




\section{Questions for respondents}

Please read to the group prior to starting the survey:

"The aim of this survey is understand what are the factors that enable maintenance or improvement of forest resource values of forests in GBAO over time.

This survey is being conducted as part of the research for a Master's in Geographical Research at the University of Cambridge. The survey will also be used to identify the factors in a village that lead to successful management of forestry resources.

By responding to this survey, you are consenting to participate. Your participation in this survey is voluntary, and you may choose not to respond to any question or terminate the survey at any time. All information that you provide in this survey will be kept strictly confidential in accordance with the research ethics guidelines of the University of Cambridge. Your response will be stored in a secure location."

6. Approximately how old is this forest? (years old) years old

7. Was this forest originally planted?

1. $\square$ No [go to Question 8]

2. $\square$ Yes

a. If yes, who planted this forest? Choose one

1. $\square$ Government

2. $\square$ NGO

3. $\square$ Local residents/farmers

4. $\square$ Local communal or forest association

5. $\square$ other

8. Is the forest accessible all year? (le. or is there flooding etc.)

1. $\square$ No

2. $\square$ Yes

9. Describe any disturbance you remember which occurred in the forest. For example: $A$ time when many trees were cut down, or a drought. 
a. How did the community deal with this disturbance?

10. How many forest users are there?

users

11. How many people in the community benefit in some way from the forest?

people

12. What is the average size of a forest plot in this forest?

ha

a. Are the forest plots approximately equal in size?

1. $\square$ Yes [go to 13]

2. $\square$ No

b. If no, please explain why the plots are of different size?

13. Who is responsible (de facto- in reality) for the operational management of this forest?

Choose only one answer.

1. $\square$ Government agency (Lezkhoz)

2. $\square$ Local group of users

3. $\square$ Private owner

4. $\square \mathrm{NGO}$

5. $\square$ Joint management between local group and government

6. $\square$ Joint management between local group and private owners

7. $\square$ Joint management between local group and an NGO

8. $\square$ Joint management between government and an NGO 
9. $\square$ Joint management between government and users

10. Other

14. Does a community-based forestry institution exist besides JFM? (IV1)

1. $\square$ No [go to question 15]

2. $\square$ Yes, but they are weak

3. $\square$ Yes, they are moderately strong

4. $\square$ Yes, they are very strong

a. If yes, what kind of institution is it and who manages it?

b. What kind of other collective action institutions exist in the community?

15. Does a group of forest tenants exist in this community?

1. $\square$ Yes

2. $\square$ No

16. Who creates the rules to maintain the forest?

a. Do forest users have the authority to change rules?
1. $\square$ Yes
2. $\square$ No

b. How many users know about the rules that guide the forestry management?
1. $\square$ No one
2. $\square$ Few people
3. $\square$ Half the people
4. $\square$ Almost everyone
5. $\square$ Everyone 
c. List the 5 most important rules in your forest and how often they are followed? (IV7)

\begin{tabular}{|l|l|l|l|l|}
\hline Rule & Never & Sometimes & Usually, yes & Always \\
\hline Rule on entry & & & & \\
\hline $\begin{array}{l}\text { Rule on } \\
\text { harvesting }\end{array}$ & & & & \\
\hline $\begin{array}{l}\text { Rule on } \\
\text { grazing }\end{array}$ & & & & \\
\hline $\begin{array}{l}\text { Rule on } \\
\text { monitoring }\end{array}$ & & & & \\
\hline
\end{tabular}

d. What rules existed to manage the forest before JFM was implemented? (can choose more than one)

1. $\square$ Water distribution

2. $\square$ Wood harvesting

3. $\square$ Controlling

4. $\square$ Monitoring

5. $\square$ Protection (rules on entry)

Please explain:

17. What types of penalties are imposed on users if they break the rules/regulations of forest usage?

For each column, list violations and penalties you are aware of for illegal cutting of firewood, timber and grazing.

\begin{tabular}{|l|l|}
\hline Violation & Penalty \\
\hline Eg. Construction wood cutting & Fine (150 somoni) \\
\hline & \\
\hline & \\
& \\
\hline
\end{tabular}




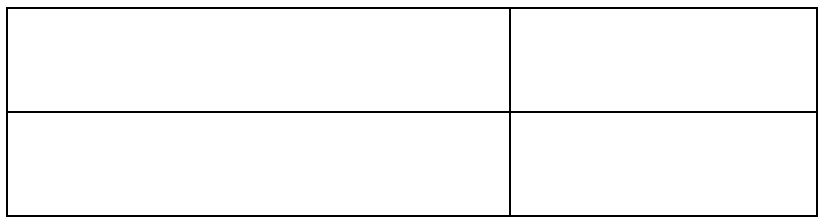

a) What are some of the historical penalties that took place during the soviet time?

18. If a cash fine is imposed, who collects the fine?

1. $\square$ The guard who apprehends a rule breaker

2. $\square$ An official of the user group

3. $\square$ An official of the Lezkhoz

4. $\square$ A local government official

5. $\square$ A national government official (outside forestry department)

6. $\square$ An official from another organization

7. $\square$ Police

19. If penalties are imposed, what is the level of compliance by the users?

1. $\square$ No one complies with the penalties imposed on them

2. $\square$ Few users comply with the penalties imposed on them

3. $\square$ About half the users comply with penalties imposed on them

4. $\square$ Most users comply with penalties imposed on them

5. $\square$ Almost all users fully comply with penalties imposed on them

6. $\square$ No penalties are imposed

20. How often does forest monitoring take place? (IV 3a) Choose only one answer.

1. $\square$ never

2. $\square$ occasionally

3. $\square$ seasonally

4. $\square$ year-round

a) Who does the monitoring?

1. $\square$ tenants

2. $\square$ Leskhoz GBAO(organization of forest)

3. $\square$ Leskhoz district

4. $\square \mathrm{GIZ}$ (sul) 
5. $\square$ GIZ (sul) and tenant

6. $\square$ other

21. Identify the frequency of forest maintenance (thinning) (IV 3b) Choose only one answer.

1. $\square$ never

2. $\square$ occasionally

3. $\square$ seasonally

4. $\square$ year-round

22. Has a disruptive conflict occurred in the past 2 years which has affected the use of resources? (IV3C) (for example over grazing)

1. $\square$ No [go to Q24]

2. $\square$ Yes

a. If yes, how did the community deal with it; how was it resolved?

23. Is any person recognized as a leader in managing the forest resources? (IV2)

1. $\square$ No

2. $\square$ Yes, but the leader is weak

3. $\square$ Yes, the leader is moderately strong

4. $\square$ Yes, the leader is very strong

24. What are the 3 primary uses of the forest?

Label most important as 1

1. $\square$ Biodiversity protection

2. $\square$ Watershed

3. $\square$ Livestock grazing

4. $\square$ Timber production

5. $\square$ Agroforestry

6. $\square$ Non-timber forest products (sea buck thorn etc.)

7. $\square$ Non-consumptive benefits (eg. Recreation)

8. $\square$ Fuelwood

9. $\square$ Fodder (e.g. alfalfa)

10. $\square$ Other 
25. Where do livestock graze around the village?

a. Are the grazing grounds outside of the forest enough to meet subsistence needs?
1. $\square$ No
2. $\square$ Yes

26. How many livestock are there in the village? (IV6c) small, and large livestock

27. Does the legal owner of each plot also hold the rights to harvest all the forest products of this plot?

1. $\square$ No

2. $\square$ Yes

28. Describe what "good forest condition" means to you?

29. Do you think the condition of your forest is better or worse than other ecologically similar forests in the region? Please rank from 1 (worst) to 5 (best). (DV1)

1. $\square$ Much worse

2. $\square$ Worse

3. $\square$ The Same

4. $\square$ Better

5. $\square$ Much better

a. Why is your forest in better or worse condition than others?

b. What are the changes in management in your forest that have occurred in the past 10 years? If any? 
30. Has the average volume of fuel wood in the forest changed in the past 5 years? (DV2a)

1. $\square$ No, it has stayed the same

2. $\square$ Yes, it has increased

3. $\square$ Yes, it has decreased

If yes, list the 3 most important reasons for change in the volume of fuel wood:

1.

2.

3.

31. Has the average volume of timber in the forest changed in the past 5 years? (DV2b)

1. $\square$ No, it has stayed the same

2. $\square$ Yes, it has increased

3. $\square$ Yes, it has decreased

If yes, list the 3 most important reasons for change in the volume of fuel wood:

1.

2.

3.

32. Is the fuelwood you are allowed to harvest not enough, sufficient, or more than you need for household consumption? (DV3a)
1. $\square$ Not enough
2. $\square$ Sufficient
3. $\square$ More than needed for household consumption

33. Is the timber you are allowed to harvest not enough, sufficient, or more than you need for household consumption? (DV3b)
1. $\square$ Not enough
2. $\square$ Sufficient
3. $\square$ More than needed for household consumption

34. Do you expect this situation of sufficiency to improve, worsen, or stay the same in the next 10 years? (DV4)
1. $\square$ Improve
2. $\square$ Worsen
3. $\square$ Stay the same 
35. Do you sell or trade excess wood (not including any other organized agreement)?

1. $\square$ No [go to 36]

2. $\square$ Yes

a. If yes, fuel wood or timber? And to where?

36. How important are forest resources for household incomes?
1. $\square$ Not important
2. $\square$ Important
3. $\square$ Very Important

37. When is the worst time for grazing to occur in the forest?
1. $\square$ Winter
2. $\square$ spring
3. $\square$ Summer
4. $\square$ Autumn

38. Has grazing in the forest increased, decreased or remained the same in the past 5 years? (IV6)
1. $\square$ Increased
2. $\square$ Decreased
3. $\square$ Stayed the same

39. What are other uses of the forest?

Tick box if yes
1. $\square$ Trees
2. $\square$ Bushes
3. $\square$ Grasses
4. $\square$ Leaves on ground
5. $\square$ Soils
6. $\square$ Stones
7. $\square$ Minerals
8. $\square$ Water
9. $\square$ Animals
10. $\square$ Areas for sacred worship
11. $\square$ Recreation 
12. $\square$ Wild plants

13.Other

40. How often do you have meetings about forest management with the following actors?

a. With other tenants?

1. $\square$ Never (No communication)

2. $\square$ Only for a particular issue

3. $\square$ Once per year or less

4. $\square$ Monthly

5. $\square$ More than monthly

b. With Leskhoz?

1. $\square$ Never (No communication)

2. $\square$ Only for a particular issue

3. $\square$ Once per year or less

4. $\square$ Monthly

5. $\square$ More than monthly

c. With GIZ staff?

1. $\square$ Never (No communication)

2. $\square$ Only for a particular issue

3. $\square$ Once per year or less

4. $\square$ Monthly

5. $\square$ More than monthly

d. With other villagers (non-tenants)?

1. $\square$ Never (No communication)

2. $\square$ Only for a particular issue

3. $\square$ Once per year or less

4. $\square$ Monthly

5. $\square$ More than monthly 


\section{Appendix: 2 Codes for Interviewees}

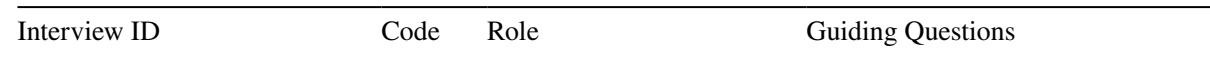

Village A: Gunt valley

1. Forest official 1

FO1

Local forest official, monitors and controls use, elder

2. Non-tenant 1

NT1 De facto user (also elder)

3. Non-tenant 2

NT2

De facto user (also elder)

4. NTFP woman 1 (transect walk)

5. Village chief

VO1

Head of village: in charge of all village systems

T1 De jure user(non-JFM)

On site

$\mathrm{T} 2$

De jure user (non-JFM)

7. Plot holder 2

8 . Focus group forest users (12 users)
FG1
How has forestry management changed over time?

How do you enforce rules?

How have violations changed over time?

What were the forests like before Soviet times?

How has land use changed?

Do you access the forest?

How does the community manage other natural resources?

As above

How do you use forest resources?

How often do you graze cattle here?

Where else do you graze your livestock?

Would you be able to survive without the forest land?

What is the distribution of land like? What kind of collection action does the community participate in?

(Mills, water, celebration, pasture)

How is the community organised?

What are the communities assets?

Challenges?

What are you responsibilities?

How do you use the forest land?

When were you given the plot?

Is there ever any conflict with nonusers?

Would you want JFM?

Are you aware of the Leskhoz rules?

Do you have enough grazing ground?

As above

What kind of community institutions exist?

How do you use the forest?

Do you have enough grazing land? Where do you graze your livestock?

What is your main source of livelihood?

How do you see the future of your forest?

Who is responsible for forestry management?

What kind of operational rules exist? 


\begin{tabular}{|c|c|c|c|}
\hline Interview ID & Code & Role & Guiding Questions \\
\hline 9. GIZ mobiliser for the area & NGO1 & $\begin{array}{l}\text { Social mobilisers, monitor } \\
\text { for the region }\end{array}$ & $\begin{array}{l}\text { What are the main challenges in the } \\
\text { region? } \\
\text { Why did the community not adopt } \\
\text { JFM? }\end{array}$ \\
\hline 10. District forest official & $\mathrm{FO} 2$ & $\begin{array}{l}\text { Head of Shugnan forestry } \\
\text { (Raiyos Koyimnazarov) }\end{array}$ & $\begin{array}{l}\text { Can you explain the Straf process? } \\
\text { How were people given land after } \\
\text { the collapse of the Soviet Union? } \\
\text { History of forest } \\
\text { How might the grazing conflicts be } \\
\text { resolved? } \\
\text { Why do you allow illegal use of } \\
\text { forest land? }\end{array}$ \\
\hline $\begin{array}{l}\text { 11. Focus group in neighbour- } \\
\text { ing village }\end{array}$ & FG2 & Neighbouring JFM forest & $\begin{array}{l}\text { Is your forest in better or worse con- } \\
\text { dition than neighbouring forests? } \\
\text { Is there conflict between users and } \\
\text { non-users? }\end{array}$ \\
\hline
\end{tabular}

Village B, Ishkashim valley
1. Head of forestry group (tenant 1)

2. Head of Jamoat

GO1

Head of the Jamoat (5
villages)

3. GIZ mobiliser for the area

4. Tenant 2

5. SUDVO Rais

GO2 Head of para-governmental structure (5 villages)

NGO2 Social mobilisers, monitor for the region
How do you use the forest land?

When were you given the plot?

When did you become leader?

How were you elected?

General area characteristics

How do the forests in the Jamoat compare?

How do you motivate people to act collectively?

How easy/hard it is to motivate people?

What is the relationship like between villages?

What are the opportunities and challenges for this community?

Are the tenants cooperative?

In your opinion, is this a well or poorly managed forest?

Do any other collective action organisation exist in the community?

Is there a clear leader in the community?

What kind of rules did the leader enforce?

Do any other collective action organisation exist in the community?

Is there a clear leader in the community?

What do you see as a solution for more sustainable forestry management? 


\begin{tabular}{|c|c|c|c|}
\hline Interview ID & Code & Role & Guiding Questions \\
\hline $\begin{array}{l}\text { 6. Head of village and VO } \\
\text { head }\end{array}$ & VO2 & $\begin{array}{l}\text { Head of village (tradi- } \\
\text { tional) and head of } \\
\text { village (para-govern- } \\
\text { mental) }\end{array}$ & $\begin{array}{l}\text { What are you main responsibilities } \\
\text { as head of village? } \\
\text { How were you elected? } \\
\text { Can you describe how people work } \\
\text { together in various management } \\
\text { systems? } \\
\text { How do you motivate people to act } \\
\text { collectively }\end{array}$ \\
\hline 7. Forest official 1 & $\mathrm{FO} 2$ & Official monitor, fines & $\begin{array}{l}\text { How has forestry management } \\
\text { changed over time? } \\
\text { How do you enforce rules? } \\
\text { How have violations changed over } \\
\text { time? }\end{array}$ \\
\hline $\begin{array}{l}\text { 8. Focus group with tenants } \\
\text { (6) }\end{array}$ & FG3 & De jure user group & $\begin{array}{l}\text { Do any other collective action } \\
\text { organisation exist in the com- } \\
\text { munity? } \\
\text { Is there a clear leader in the com- } \\
\text { munity? } \\
\text { Is there conflict with non-tenants? } \\
\text { What is your main challenge? }\end{array}$ \\
\hline 9. Tenant 3 & T5 & De jure user (JFM) & As above (T4) \\
\hline 10. Non-tenant 1 (woman) & NT4 & De facto user & $\begin{array}{l}\text { What were the forests like before } \\
\text { Soviet times? } \\
\text { How has land use changed? } \\
\text { Do you access the forest? } \\
\text { How does the community manage } \\
\text { other natural resources? }\end{array}$ \\
\hline $\begin{array}{l}\text { 11. Non-tenant } 2 \\
\text { (woman }+ \text { husband) }\end{array}$ & NT5 & De facto user & $\begin{array}{l}\text { What were the forests like before } \\
\text { Soviet times? } \\
\text { How has land use changed? } \\
\text { Do you access the forest? } \\
\text { How does the community manage } \\
\text { other natural resources? }\end{array}$ \\
\hline 12. Tenant 3 & NT6 & De jure user (JFM) & As above (T4) \\
\hline $\begin{array}{l}\text { 13. Focus group non-tenants } \\
\text { ( } 3 \text { women, } 2 \text { men) }\end{array}$ & FG4 & De facto user group & $\begin{array}{l}\text { Do you use the forest? } \\
\text { Do you think the forest is managed } \\
\text { well? Fairly? } \\
\text { 'Do you think the way tenants were } \\
\text { chosen was fair? }\end{array}$ \\
\hline 14. Elder 1 (son tenant) & T6 & De jure user & $\begin{array}{l}\text { How has the village structure } \\
\text { changed over time (pre-Soviet, } \\
\text { Soviet, post-Soviet?) } \\
\text { How did the forest quality, and } \\
\text { management change? }\end{array}$ \\
\hline \multicolumn{4}{|c|}{ Village $C$, Ishkashim valley/Wakhan corridor } \\
\hline 1. Focus group 1 & $F G 5$ & De jure users (3 men) & $\begin{array}{l}\text { Do any other collective action } \\
\text { organisation exist in the com- } \\
\text { munity? } \\
\text { Is there a clear leader in the com- } \\
\text { munity? } \\
\text { What kind of rules did the leader } \\
\text { enforce? }\end{array}$ \\
\hline
\end{tabular}




\begin{tabular}{|c|c|c|c|}
\hline Interview ID & Code & Role & Guiding Questions \\
\hline 2. Tenant 1 & $T 7$ & De jure user & $\begin{array}{l}\text { When did you become a tenant? } \\
\text { What happens if rules are broken? } \\
\text { Why do you protect the forest if you } \\
\text { are not paid? } \\
\text { Before the JFM system, how id you } \\
\text { know how much to harvest? }\end{array}$ \\
\hline 3. Head of village & VO3 & $\begin{array}{l}\text { Head of village (tradi- } \\
\text { tional) and head of } \\
\text { village (para-govern- } \\
\text { mental) }\end{array}$ & $\begin{array}{l}\text { What are you main responsibilities } \\
\text { as head of village? } \\
\text { How were you elected? } \\
\text { Can you describe how people work } \\
\text { together in various management } \\
\text { systems? } \\
\text { How do you motivated people to act } \\
\text { collectively? }\end{array}$ \\
\hline
\end{tabular}

4. Rais Khojagi Dekhoni

5. Elder and wife (nontenants)

6. Former head of village

7. Mirjou (water master)

8. Focus group 2

9. Focus group 3

10. Forest leader
FG7

Non-tenants women and $\operatorname{men}(8)$

GO3 Head of village land committee

NT7 De facto users, elder

VO4

De facto user, elder, museum curator, author

VO5 Water master; controls distribution of water in the village

FG6 Women from tenant households (5)

T8 (Transect walk)
What is the distribution of cops

Is there enough pasture

land?

How are the association lands distributed?

How do the taxes for the different land categories work?

How has the village structure changed over time (pre-Soviet, Soviet, post-Soviet?)

How did the forest quality, and management change?

What is the history of the two shrines in Namadgut?

Why did you decide that the forests were important?

How did you motivate people to act collectively?

What are your main responsibilities?

What is the water schedule?

What kind of collective action exists around water management?

Is there ever conflict around water? How is it resolved?

How often do you go to the forest?

What are the main products you use?

Do any informal rules on grazing exist?

Why is the forest important to you?

Do you use the forest?

Do you think the forest is managed well? Fairly?

Do you think the way tenants were chosen was fair?

What are the main uses of your plot?

Why were you chosen as forest leader?

How do you enforce rules? 


\begin{tabular}{|c|c|c|c|}
\hline Interview ID & Code & Role & Guiding Questions \\
\hline 11. Tenant 2 & T9 & Woman (transect walk) & $\begin{array}{l}\text { - What are the main uses of your } \\
\text { plot? } \\
\text { - Do you use NTFP? } \\
\text { - Why, as a woman, did you want to } \\
\text { become a forest tenant? Do you } \\
\text { face particular difficulties? }\end{array}$ \\
\hline & \multicolumn{3}{|l|}{ Khorog } \\
\hline 1. Retired forest official & FO3 & Head of forestry, retired & $\begin{array}{l}\text { How has forest management } \\
\text { changed over time? } \\
\text { Why did you start foresting } \\
\text { Ishkashim area? } \\
\text { How did Leskhoz adjust to changes } \\
\text { in government? }\end{array}$ \\
\hline $\begin{array}{l}\text { 2. Regional government } \\
\text { official } 1\end{array}$ & FO4 & $\begin{array}{l}\text { Land management } \\
\text { Shugnan }\end{array}$ & $\begin{array}{l}\text { What is the distribution of pasture in } \\
\text { the district? } \\
\text { How much agricultural land? } \\
\text { How much pasture land? } \\
\text { Land conflict? }\end{array}$ \\
\hline 3. MSDSP 1 & NGO3 & NRM official & $\begin{array}{l}\text { How many villages and jamoats } \\
\text { selected forestry as a management } \\
\text { priority? } \\
\text { Do any saving's groups use funds } \\
\text { for forestry management or other } \\
\text { natural resource management? }\end{array}$ \\
\hline 4. MSDSP 2 & NGO4 & Civil Society official & $\begin{array}{l}\text { How does your community saving's } \\
\text { group work? }\end{array}$ \\
\hline 5. Forest Official & FO4 & $\begin{array}{l}\text { Head of land-use specifi- } \\
\text { cation }\end{array}$ & $\begin{array}{l}\text { What were the main goals in affor- } \\
\text { esting Ishkashim valley? } \\
\text { What are the main changes that } \\
\text { occurred since the } 1970 \mathrm{~s} \text { ? }\end{array}$ \\
\hline
\end{tabular}

\section{References}

Agrawal, A. (2001). Common property institutions and sustainable governance of resources. World Development, 29(10), 1649-1672. https://doi.org/10.1016/S0305-750X(01)00063-8.

Agrawal, A., \& Chhatre, A. (2006). Explaining success on the commons: Community forest governance in the Indian Himalaya. World Development, 34(1), 149-166. https://doi.org/10.1016/j.world dev.2005.07.013.

Agrawal, A., \& Gupta, K. (2005). Decentralization and participation: The governance of common pool resources in Nepal's Terai. World Development, 33(7), 1101-1114. https://doi.org/10.1016/j.world dev.2005.04.009.

Agrawal, A., \& Yadama, G. (1997). How do local institutions mediate market and population pressures on resources? Forest panchayats in Kumaon. India. Development and Change, 28(3), 435-465. https://doi. org/10.1111/1467-7660.00050.

Anderies, J. (2004). A framework to analyze the robustness of social-ecological systems from an institutional perspective. Ecology and Society., 9(1), 18.

Baland, J.-M., \& Platteau, J.-P. (1996). Halting degradation of natural resources: Is there a role for rural communities? Food and Agriculture Organisation. Biddles Ltd, Guildford King's Lynn, UK. ISBN: 92-5-103728-0.

Ban, N. C., \& Cox, M. (2017). Advancing social-ecological research through teaching: summary, observations, and challenges. Ecology and Society. https://doi.org/10.5751/ES-08949-220106. 
Barnes, C., \& Van Laerhoven, F. (2013). Helping to self-help? External interventions to stimulate local collective action in Joint Forest Management, Maharashtra, India. International Forestry Review, 15(1), 1-17. https://doi.org/10.1505/146554813805927246.

Basurto, X., Gelcich, S., \& Ostrom, E. (2013). The social-ecological system framework as a knowledge classificatory system for benthic small-scale fisheries. Global Environmental Change, 23(6), 13661380. https://doi.org/10.1016/j.gloenvcha.2013.08.001.

Berkes, F. (1989). Common property resources: Ecology and community-based sustainable development. Belhaven Press with the International Union for Conservation of Nature and Natural Resources.

Biggs, R., Westley, F. R., \& Carpenter, S. R. (2010). Navigating the back loop: Fostering social innovation and transformation in ecosystem management. Ecology and Society, 15(2), 9. https://doi. org/10.2307/26268153.

Blaikie, P. (2006). Is small really beautiful? Community-based natural resource management in Malawi and Botswana. World Development, 34(11), 1942-1957. https://doi.org/10.1016/j.worlddev.2005.11.023.

Bliss, F. (2006). Social and economic change in the Pamirs (Gorno-Badakhshan. Tajikistan): Routledge.

Breu, T., \& Hurni, H. (2003). The Tajik Pamirs: Challenges of sustainable development in an isolated mountain region. Berne.

Breu, T., Maselli, D., \& Hurni, H. (2005). Knowledge for sustainable development in the Tajik Pamir mountains. Mountain Research and Development, 25(2), 139-146. https://doi.org/10.1659/02764741(2005)025[0139:KFSDIT]2.0.CO;2.

Brosius, J. P., Tsing, A. L., \& Zerner, C. (1998). Representing communities: Histories and politics of community-based natural resource management. Society \& Natural Resources, 11(2), 157-168. https://doi. org/10.1080/08941929809381069.

Chhatre, A., \& Agrawal, A. (2008). Forest commons and local enforcement. Proceedings of the National Academy of Sciences of the United States of America, 105(36), 13286-13291. https://doi.org/10.1073/ pnas.0803399105.

Coleman, E. A. (2011). Common property rights, adaptive capacity, and response to forest disturbance. Global Environmental Change, 21(3), 855-865. https://doi.org/10.1016/j.gloenvcha.2011.03.012.

Cox, M., Arnold, G., \& Tomas, S. V. (2010). A review of design principles for community-based natural resource management. Ecology and Society, 15(4), 38. https://doi.org/10.5751/ES-03704-150438.

Creswell, J. W. (2007). Qualitative inquiry and research design: Choosing among five approaches. Thousand Oaks: Sage Publications Inc.

Daedlow, K., Beckmann, V., Schlüter, M., \& Arlinghaus, R. (2013). Explaining institutional persistence, adaptation, and transformation in East German recreational-fisheries governance after the German reunification in 1990. Ecological Economics, 96, 36-50. https://doi.org/10.1016/j.ecole con.2013.09.005.

Darnhofer, I., Lamine, C., Strauss, A., \& Navarrete, M. (2016). The resilience of family farms: Towards a relational approach. Journal of Rural Studies, 44, 111-122. https://doi.org/10.1016/J.JRURS TUD.2016.01.013.

Epstein, G., Vogt, J. M., Mincey, S., Cox, M., \& Fischer, B. (2013). Missing ecology : integrating ecological perspectives with the social-ecological system framework. International Journal of the Commons, $7(2), 432-453$.

Folke, C. (2006). Resilience: The emergence of a perspective for social-ecological systems analyses. Global Environmental Change, 16(3), 253-267.

Folke, C., Biggs, R., Norström, A. V., Reyers, B., \& Rockström, J. (2016). Social-ecological resilience and biosphere-based sustainability science. Ecology and Society. https://doi.org/10.5751/ES-08748-21034 1.

Folke, C., Carpenter, S. R., Walker, B., Scheffer, M., Chapin, T., \& Rockström, J. (2010). Resilience thinking: Integrating resilience, adaptability and transformability. Ecology and Society, 15(4), 10.

Gibson, C. C., Williams, J. T., \& Ostrom, E. (2005). Local enforcement and better forests. World Development, 33(2), 273-284. https://doi.org/10.1016/j.worlddev.2004.07.013.

Giffen, J., Earle, L., \& Buxton, C. (2005). The development of civil society in central Asia. INTRAC.

GIZ. (2012). Linking natural resource management and adaptation to climate change: Experiences from the Tajik Pamirs. Bonn and Eschborn (Germany).

Goulden, M. C., Adger, W. N., Allison, E. H., \& Conway, D. (2013). Limits to resilience from livelihood diversification and social capital in lake social-ecological systems. Annals of the Association of American Geographers, 103(4), 906-924. https://doi.org/10.1080/00045608.2013.765771.

Gunderson, L. H., \& Holling, C. S. (2002). Panarchy: Understanding transformations in human and natural systems. Washington DC: Island Press.

Herbers, H. (2001). Transformation in the Tajik Pamirs : Gornyi-Badakhshan-an example of successful restructuring? Central Asian Survey, 20(3), 367-381. https://doi.org/10.1080/0263493012009536. 
Hergarten, C. (2004). Investigations on land cover and land use of Gorno Badakhshan (GBAO) by means of land cover classifications derived from LANDSAT 7 data making use of remote sensing and GIS techniques. Bern: Universität Bern.

International Forestry Resource and Institutions. (2008). IFRI field manual. Update.

Kassam, K. S. (2010). Pluralism, resilience, and the ecology of survival: Case studies from the Pamir Mountains of Afghanistann. Ecology and Society, 15(2), 1-19.

Kirchoff, J. F. \& Fabian, A. (2010). Forestry sector analysis of the Republic of Tajikistan. Eschborn, Germany: GTZ [Deutsche Gesellshaft für Technische Zusammenarbeit].

Kreutzmann, H. (2003). Ethnic minorities and marginality in the Pamirian Knot: survival of Wakhi and Kirghiz in a harsh environment and global contexts. Distribution, 169(3), 215-235.

Kumar, S. (2002). Does "Participation" in common pool resource management help the poor? A social costbenefit analysis of joint forest management in Jharkhand, India. World Development, 30(5), 763-782.

Lacroix, K., \& Richards, G. (2015). An alternative policy evaluation of the British Columbia carbon tax: Broadening the application of Elinor Ostrom's design principles for managing common-pool resources. Ecology and Society. https://doi.org/10.5751/ES-07519-200238.

Leach, M., Mearns, R., \& Scoones, I. (1999). Environmental entitlements: Dynamics and institutions in community-based natural resource management. World Development, 27(2), 225-247. https://doi. org/10.1016/S0305-750X(98)00141-7.

Leslie, H. M., Basurto, X., Nenadovic, M., Sievanen, L., Cavanaugh, K. C., Cota-Nieto, J. J., et al. (2015). Operationalizing the social-ecological systems framework to assess sustainability. Proceedings of the National Academy of Sciences of the United States of America, 112(19), 5979-5984. https://doi. org/10.1073/pnas.1414640112.

Lund, J. F., Rutt, R. L., \& Ribot, J. (2018). Trends in research on forestry decentralization policies. Current Opinion in Environmental Sustainability, 32, 17-22. https://doi.org/10.1016/j.cosust.2018.02.003.

Lynch, O. J., Owen, J., \& Talbott, K. (1995). Balancing acts: Community-based forest management and national law in Asia and the Pacific. Washington DC: World Resources Institute.

MacNally, R. (2002). Multiple regression and inference in ecology and conservation biology: further comments on identifying important predictor variables. Biodiversity and Conservation, 11, 1397-1401. https://doi.org/10.1023/A:1016250716679.

MacNally, R., \& Walsh, C. J. (2004). Hierarchical partitioning public-domain software. Biodiversity and Conservation, 13, 659-660. https://doi.org/10.1023/B:BIOC.0000009515.11717.0b.

Mahoney, J. (2000). Path dependence in historical sociology. Theory and Society, 29(4), 507-548. https:// doi.org/10.1023/A:1007113830879.

McGinnis, M. D., \& Ostrom, E. (2014). Social-ecological system framework: initial changes and continuing challenges. Ecology and Society. https://doi.org/10.5751/ES-06387-190230.

Miles, M. B., \& Huberman, A. M. (1994). Qualitative data analysis: An expanded sourcebook. Thousand Oaks: Sage.

Mislimshoeva, B., Herbst, P., \& Koellner, T. (2016). Current pathways towards good forest governance for ecosystem services in the former Soviet republic Tajikistan. Forest Policy and Economics, 63, 11-19. https://doi.org/10.1016/J.FORPOL.2015.12.002.

Nagendra, H. (2007). Drivers of reforestation in human-dominated forests. Proceedings of the National Academy of Sciences of the United States of America, 104(39), 15218-15223. https://doi.org/10.1073/ pnas.0702319104.

Ostrom, E. (1990). Governing the commons: The evolution of institutions for collective action (Vol. 1990). Cambridge: Cambridge University Press.

Ostrom, E. (2007). A diagnostic approach for going beyond panaceas. Proceedings of the National Academy of Sciences of the United States of America, 104(39), 15181-15187.

Ostrom, E. (2009). A general framework for analyzing sustainability of social-ecological systems. Science (New York, N.Y.), 325(5939), 419-422. https://doi.org/10.1126/science.1172133.

Ostrom, E., Burger, J., Field, C. B., Norgaard, R. B., \& Policansky, D. (1999). Revisiting the commons: Local lessons, global challenges. Science. https://doi.org/10.1126/science.284.5412.278.

Patton, M. Q. (2002). Qualitative research and evaluation methods. Thousand Oaks: SAGE.

Pierson, P. (2004). Politics in time: History, institutions, and social analysis. Princeton: Princeton University Press.

Poteete, A. R., Janssen, M. A., \& Ostrom, E. (2010). Working together: Collective action, the commons, and multiple methods in practice. New York: Princeton University Press.

Quinn, C. H., Huby, M., Kiwasila, H., \& Lovett, J. C. (2007). Design principles and common pool resource management: an institutional approach to evaluating community management in semi-arid Tanzania. Journal of Environmental Management, 84(1), 100-113. 
R Core Team (2013). R: A language and environment for statistical computing. Foundation for Statistical Computing. Vienna, Austria. http://www.r-project.org/.

Resilience Alliance (2010). Assessing resilience in social-ecological systems: Workbook for practitioners 2.0. http://www.resalliance.org/3871.php\%0A2.

Robinson, E. J. Z., Kumar, A. M., \& Albers, H. J. (2010). Protecting developing countries' forests: Enforcement in theory and practice. Journal of Natural Resources Policy Research, 2(1), 25-38. https://doi. org/10.1080/19390450903350820.

Saigal, S. (2003). Tajikistan: Issues and approaches to combat desertification. Asian Development Bank: TA 5941-REG: Combating Desertification in Asia.

Shackleton, S., et al. (2002). Devolution and community based natural resource management: Creating space for local people to participate and benefit? Overseas Development Institute: Natural Resources Perspectives, 76, 1-6.

'Tajikistan clashes: 'Many dead in Gorno-Badakshan,' British Broadcasting Corporation (24 July 2012): http://www.bbc.com/news/world-asia-18965366. Accessed July 7, 2014.

Taggart-Hodge, T. D., \& Schoon, M. (2016). The challenges and opportunities of transboundary cooperation through the lens of the East Carpathians Biosphere Reserve. Ecology and Society. https://doi. org/10.5751/ES-08669-210429.

Tajikistan (2011). The forest code of the Republic of Tajikistan. http://www.wildlife-tajikistan.org/downl oads/viewcategory/6. Accessed March 2, 2018.

True, J. L., Jones, B. D., \& Baumgartner, F. R. (2007). Punctuated-equilibrium theory explaining stability and change in public policymaking. In P. A. Sabatier (Ed.), Theories of the policy process (pp. 155-188). Boulder: Westview Press.

Tyson, W. (2017). Using social-ecological systems theory to evaluate large-scale comanagement efforts: A case study of the Inuvialuit Settlement Region. Ecology and Society, 22(1), 5.

United Nations Statistics Division (2013). Tajikistan: world statistics pocketbook. http://data.un.org/Count ryProfile.aspx?crname=Tajikistan. Accessed July 7, 2014.

van Oudenhoven, F., \& Haider, L. J. (2012). Imagining alternative futures through the lens of food in the Afghan and Tajik Pamir Mountains. Revue D'ethnoecologie, 2, 2-18.

van Oudenhoven, F., \& Haider, J. (2015). With our own hands: A celebration of food and life in the Pamir mountains of Afghanistan and Tajikistan. Utrecht: LM Publishers.

Walker, B. H., Carpenter, S. R., Rockstrom, J., Crepin, A.-S., \& Peterson, G. D. (2012). Ecology and society: Drivers, "Slow" variables, "Fast" variables, shocks, and resilience. Ecology And Society, 17(3), 30 .

World Bank. (2009). Republic of Tajikistan poverty assessment: Report no. 51341-TJ. Human Development Sector Unit Central Asia Country Unit, Europe and Central Asia Region.

Wright, G. D., Andersson, K. P., Gibson, C. C., Evans, T. P., \& Turner, B. L. (2016). Decentralization can help reduce deforestation when user groups engage with local government. Proceedings of National Academy of Sciences, 113(52), 14958-14963. https://doi.org/10.1073/pnas.1610650114. 